Review Article

\title{
Additive Manufacturing: A Novel Method for Developing an Acoustic Panel Made of Natural Fiber-Reinforced Composites with Enhanced Mechanical and Acoustical Properties
}

\author{
Vignesh Sekar $(\mathbb{D}$, Mohammad Hosseini Fouladi $\mathbb{D}$, Satesh Narayana Namasivayam $\mathbb{D}$, \\ and Sivakumar Sivanesan
}

School of Engineering, Taylor's University, No. 1 Jalan Taylor's, 47500 Subang Jaya, Selangor, Malaysia

Correspondence should be addressed to Mohammad Hosseini Fouladi; mfoolady@gmail.com

Received 18 June 2019; Accepted 30 August 2019; Published 18 September 2019

Academic Editor: Yuanxin Zhou

Copyright (C) 2019 Vignesh Sekar et al. This is an open access article distributed under the Creative Commons Attribution License, which permits unrestricted use, distribution, and reproduction in any medium, provided the original work is properly cited.

Natural fibers and their composites are being widely used in almost all the applications in this modern era. However, the properties of natural fibers have to be enhanced in order to compete with synthetic fibers. This review paper opens up additive manufacturing, as a novel method for developing an acoustic panel using natural fiber composites with enhanced mechanical and acoustical properties. This approach will help to replace synthetic-based acoustic absorbers with biodegradable composite panels in acoustic applications. This review also covers, poly(lactic acid) as a polymer matrix and its advantages, the available variety of natural fibers as reinforcement in terms of mechanical and acoustical properties. The natural fiber-based filaments used in additive manufacturing and acoustic panels made from the available natural fibers are also elaborated here. This review shows the importance of additive manufacturing and its application to develop novel acoustic panels made of agricultural waste.

\section{Introduction}

Additive manufacturing (AM), which is also known as $3 \mathrm{D}$ printing, is the process of combining materials to construct a three-dimensional object layer by layer. The input will be from the 3D model data which are drafted in designing software [1]. Additive manufacturing is used in many manufacturing divisions such as automotive, biomedical, and aerospace [2]. According to ISO/ASTM 52900, AM is classified into multistep process and single step process. The processes are categorized into binder jetting, directed energy deposition, material extrusion, material jetting, and powder bed fusion. Based on the materials used in the AM process, there are mainly three types of $3 \mathrm{D}$ printing methods available and they are liquid-, solid-, and powder-based AM. Stereo lithography (SL), fused deposition modeling (FDM), and polyjet are liquid-based AM. Laminated object manufacturing (LOM) is the solid-based AM. Powder bed and inkjet head 3D printing (3DP), prometal, laminated engineered net shaping (LENS), selective laser sintering (SLS), and electron beam melting are powder-based AM [3]. Out of all techniques, FDM is the most common technique used for printing fiber-reinforced polymer composites [4]. One of the main drawbacks of the FDM technique is that the printed composites will have slight void formation between the deposition lines [5]. This void formation in the additive manufacturing process can be turned as a favor for acoustical applications since acoustic absorption panels need a modest range of pores or voids to absorb the sound waves effectively [6]. In order to get the desired product with enhanced properties, filaments which are produced for the AM process has to be durable and resistant [7]. There are lots of materials that have been used in the additive manufacturing process. Some of the materials which have been in practices are pure polymers, polymer matrix composites, polymer ceramic composites, nanocomposites, and fiber-reinforced composites [2]. Recently, natural fiberreinforced composite (NFRC) filaments seek attention in the field of AM as NFRC is economical and highly biodegradable 
and exhibits lower environmental impacts [8]. Malaysia is aiming for national target of $40 \%$ reduction in carbon emissions by 2020. Unfortunately, as per the carbon foot print report circulated by Roundtable on Sustainable Palm Oil (RSPO), it is found that net carbon emission in 2017 has increased by around 18\% since 2014, from under 350,000 MT $\mathrm{CO}_{2} \mathrm{e}$ to $420,000 \mathrm{MT} \mathrm{CO}_{2} \mathrm{e}$ which has to be taken into an account [9]. The use of synthetic fibers will have environmental impacts like increased carbon footprint level during its entire life span [10], whereas bio-based polymers like PLA show lesser environmental impacts and proved to be an alternative for petroleum-based polymers [11].

\section{Acoustic Panels Made of Natural Fibers and Their Evolution}

Noise which originates from industries and residences is more bothering as they cause sleeping disturbances, headache, annoyance, and stress among the people. Hence, these noises have to be addressed immediately [12]. Acoustic panels can be used in controlling the sound by absorbing it and converting it into heat energy. Generally, acoustic panels will be containing porous synthetic materials like polyester, rock wool, and glass wool. Recently, acoustic panels made of natural fibers are becoming a trend. This is because most of the natural fibers are proven to be good acoustic absorbers and cost-effective [13]. Perforated panels are the one that support the usage of natural fibers in it. Usually, conventional perforated panels will be having holes with a larger diameter which could not provide satisfactory acoustic absorption. This problem leads to the discovery of microperforated panels which has a smaller diameter of pores in it [14]. In an acoustic panel made of natural fibers, its acoustic absorption is influenced by some of the factors like the fiber morphology, content of fiber, position of perforated plates, treatment of fiber, and so forth. In order to study about the position of perforation plates, Hosseini et al. placed perforation plates before and after the fiber layers and concluded that placing of perforation plates both before and after the fiber layers was eligible to increase acoustic absorption [15]. Bansod et al. placed the circular perforated plate made of mild steel plates in a circular pattern at both sides of fiber layers and observed that if the perforation plates are kept behind, there is an improvement in acoustic absorption in the high-frequency spectrum [16]. To know about the effect of fiber content on the acoustic absorption coefficient, Daniel et al. mixed the kenaf fibers in different ratios with PLA and hot pressed into a microperforated plate. They found that the composite with $30 \%$ of percentage of kenaf fibers has shown the maximum absorption coefficient [14]. Ismail et al. bonded the rice husk and sugarcane bagasse at different fiber contents using phenol formaldehyde resin which is later hot pressed into an acoustic panel. They determined that voids in rice husk encouraged acoustic absorption, whereas sugarcane bagasse offered sturdiness to the panel [17]. To study the effect of alkaline treatment on the acoustic absorption, Sari et al. molded the corn husk fibers which are treated with different ratios of sodium hydroxide into an acoustic panel. They found the fibers which are treated with $2 \%$ and $5 \%$ of $\mathrm{NaOH}$ exhibit a higher absorption coefficient [18]. In order to investigate about densities and thickness of fiber layers, Rachman et al. mixed the coir fibers at different densities with acetic acid as an adhesive at different percentage and hot pressed into an acoustic panel. Acoustic absorption coefficient was calculated. It has been found that sample with the higher density and lower percentage of acetic acid provides the highest acoustic absorption coefficient [19]. Berardi et al. made an acoustic panel by molding the fibers from coir, kenaf, wood, and hemp at different thickness of layers and concluded that acoustic absorption can be increased by increasing the thickness of the layers [13]. Liu et al. 3D-printed the perforated panel using polymer materials called VisiJet-SL (Clear) backed with recycled cotton fibers and revealed that the acoustic absorption coefficient can be varied by varying the perforation ratio [6]. Table 1 shows some of the acoustic panels made of natural fibers and their composites along with its methodology and key findings.

Apart from the abovementioned acoustic panels, these are also some of the acoustic panels made of natural fibers. Kang and Brocklesby produced a transparent microperforated plate in the acoustic window system and realized this system can be used for solar application [20]. Iannace et al. produced an acoustic panel by stuffing giant reeds in jute bags and conducted a case study to use the produced panel for classrooms [21]. Kaamin et al. stuffed kapok fiber in an egg tray and developed an acoustic panel which showed promising acoustical properties [22]. Chou et al. developed an interior adjustable acoustic panel which is suitable for adjusting the reverberation time without fixing up the whole room [23]. Acoustic insulation boards were developed using materials like sheep wool and green composites in different compositions, and they concluded these sound boards can be used for light weight applications [24]. These are some of the ways by which acoustic panels are made from natural fibers, whereas $3 \mathrm{D}$ printing of an acoustic panel made of natural fiber-reinforced composite is still to get recognized.

\section{Recent Trends in Additive Manufacturing of NFRCs}

At first, synthetic fibers made their way into the field of additive manufacturing. A review report by Goh et al. concluded that mechanical properties of the $3 \mathrm{D}$ printed composites are increased when reinforcements are added into the pure polymers. This report mainly dealt with synthetic fibers [25]. Some of the results based on the reinforcement of synthetic fibers are summarized as follows: Zhong et al. reinforced glass fibers with $A B S$ as a matrix using FDM technology and found that the ABS-glass fiber composite exhibits better strength than pure polymer [26]. Tekinalp et al. reinforced carbon fibers with ABS and observed that increase in fiber content shows increased modulus and tensile strength which is greater than the conventional compression molding [5]. Table 2 shows some of the synthetic fibers that have been used in the FDM process and their enhancements. 
TABle 1: Acoustic panels made of natural fibers and their composites along with the methodology and key findings.

\begin{tabular}{|c|c|c|c|c|}
\hline Materials used & Methodology & $\begin{array}{c}\text { Factors investigated } \\
\text { considering acoustic } \\
\text { absorption }\end{array}$ & Key findings & References \\
\hline Coir fiber & $\begin{array}{l}\text { Perforated plates backed by } \\
\text { coir fibers }\end{array}$ & $\begin{array}{c}\text { Position of perforation plate } \\
\text { and air gap }\end{array}$ & $\begin{array}{c}\text { Acoustic absorption was } \\
\text { improved especially in low } \\
\text { frequency spectrum }\end{array}$ & {$[15]$} \\
\hline Jute felts & $\begin{array}{l}\text { Perforated plates backed by } \\
\text { jute felts }\end{array}$ & $\begin{array}{l}\text { Position of perforation plate } \\
\text { and thickness of backed fiber }\end{array}$ & $\begin{array}{l}\text { Usage of perforation plates } \\
\text { helped in improving the } \\
\text { acoustic absorption in low } \\
\text { frequency spectrum without } \\
\text { increasing the jute belt's } \\
\text { thickness }\end{array}$ & {$[16]$} \\
\hline Kenaf fiber & $\begin{array}{l}\text { Hot pressing of the perforated } \\
\text { plate }\end{array}$ & Fiber content & $\begin{array}{l}\text { The highest acoustic } \\
\text { absorption coefficient was } \\
\text { recorded as } 0.987 \text { at } \\
1521.02 \mathrm{~Hz}\end{array}$ & {$[14]$} \\
\hline $\begin{array}{l}\text { Rice husks and sugarcane } \\
\text { bagasse }\end{array}$ & $\begin{array}{l}\text { Hot pressing of the perforated } \\
\text { plate }\end{array}$ & Fiber content & $\begin{array}{l}\text { The highest acoustic } \\
\text { absorption coefficient was } \\
\text { recorded as } 0.58 \text { at } 4000 \mathrm{~Hz}\end{array}$ & {$[17]$} \\
\hline Coir & Hot pressing of the fiber & Density of the fiber layer & $\begin{array}{c}\text { Acoustic absorption } \\
\text { coefficient was observed to be } \\
0.9 \text { at } 4000 \mathrm{~Hz}\end{array}$ & {$[19]$} \\
\hline Corn husk fiber & Molding of fibers & Alkaline treatment of fibers & $\begin{array}{c}\text { Acoustic absorption } \\
\text { coefficient was } 100 \% \text { in the } \\
\text { frequency range between } 1600 \\
\text { and } 3250 \mathrm{~Hz}\end{array}$ & {$[18]$} \\
\hline $\begin{array}{l}\text { Kenaf fiber, wood fiber, hemp } \\
\text { fiber, and coconut fiber }\end{array}$ & Molding of fibers & Thickness of the fiber layer & $\begin{array}{l}\text { All the natural fibers exhibited } \\
\text { satisfactory acoustic } \\
\text { absorption coefficient in } \\
\text { midfrequency and high } \\
\text { frequency spectrums }\end{array}$ & {$[13]$} \\
\hline Recycled cotton fiber & $\begin{array}{l}\text { 3D printed perforated plate } \\
\text { made of VisiJet-SL (clear) } \\
\text { backed by recycled cotton } \\
\text { fibers }\end{array}$ & Perforation ratio & $\begin{array}{l}\text { Significant improvement of } \\
\text { acoustic absorption especially } \\
\text { in low to midfrequency } \\
\text { spectrum }\end{array}$ & {$[6]$} \\
\hline Natural fiber composites & $\begin{array}{l}\text { 3D printing of an acoustic } \\
\text { panel }\end{array}$ & - & - & $\begin{array}{l}\text { This } \\
\text { review }\end{array}$ \\
\hline
\end{tabular}

TABLe 2: Synthetic fiber reinforcement in polymer and their enhancement [4].

\begin{tabular}{lc}
\hline Composite & Enhancement in properties \\
\hline Short glass fiber-ABS & $\begin{array}{c}\text { Tensile strength of the composite increases by } 135 \% . \\
\text { The maximum tensile strength is found at } 18 \% \text { fiber } \\
\text { content. }\end{array}$ \\
Short carbon fiber-ABS & $\begin{array}{c}\text { Tensile strength of the composite increases by } 114 \% . \\
\text { The maximum tensile strength is obtained at } 40 \% \\
\text { fiber content. }\end{array}$ \\
Continuous carbon fiber-nylon & $\begin{array}{c}\text { Tensile strength of the composite increases by } 465 \% . \\
\text { The maximum tensile strength is peaked at 34\% fiber } \\
\text { content. }\end{array}$ \\
Continuous carbon fiber-PLA & $\begin{array}{c}\text { Tensile strength of the composite increases by } 332 \% . \\
\text { The maximum tensile strength is obtained at } 6.6 \text { wt.\%. }\end{array}$
\end{tabular}

According to Table 2, synthetic fiber reinforcement in the polymer matrix by the FDM process has shown a greater increase in mechanical property of the composites. Considering cost and environmental impact, reinforcement using natural fibers evolved [27]. Only limited research studies have been done in $3 \mathrm{D}$ printing of the natural fiber-reinforced composite received from fruits and plants. Stoof and Pickering initiated an experiment to $3 \mathrm{D}$ print the natural fiberreinforced composite. They have successfully $3 \mathrm{D}$ printed the composite by reinforcing harakeke fiber and hemp fiber with PLA as a polymer matrix and made few conclusions as follows: $10 \%$ fiber content of hemp shows increased tensile than 
the polymer matrix and the tensile strength tends to decrease with an increase in the fiber content, whereas in case of harakeke fibers, tensile strength was noted to be decreased for $10 \%$ fiber content initially. Then, the tensile strength tends to increase for 20\% fiber content [28]. Recent review article by Mazzanti et al. covered the research studies made on the 3D printed natural fiber composites and the factors influencing its mechanical properties and concluded that the addition of natural fibers as reinforcement increases the mechanical properties in few cases. They also added that the increase in percentage of natural fibers to the PLA decreases the strength of the composite, whereas the stiffness of the composite remains the same. Impact strength and elongation at break decreases with addition of natural fibers. On an overall basis, it can be seen that the mechanical properties of the $3 \mathrm{D}$ printed natural fiber composites has not increased drastically when compared to pure polymers. However, the mechanical properties of the 3D printed composites can be further enhanced by optimizing some of the process parameters (nozzle diameter, filament diameter, printing speed, melting temperature, infill geometry, infill thickness, number of layers, and thickness of layers), product parameters (fiber geometry and fiber morphology), and environmental conditions (humidity). From all the research and review made on $3 \mathrm{D}$ printed natural fiber composites, it can be commonly seen that the surface of the 3D printed composite contains gap, cracks, and pores. This pore, crack, and gap formation is considered as limitation in many of the research and review related to 3D printing of the fiber-reinforced composites [29]. The same characteristics was observed even in the $3 \mathrm{D}$ printed synthetic fiber composites [30]. Table 3 shows some of the research studies on $3 \mathrm{D}$ printing of the natural fillers along with discussion.

This void formation in the $3 \mathrm{D}$ printing process can be turned as an advantage in acoustical applications since surface of the acoustic absorbing devices needs perforation for its effective acoustical absorption [6]. As of present, physical properties, mechanical properties, rheological properties, and some other characteristics like water absorption, warping, and phase morphology of the 3D printed NFRC were investigated by the researchers, whereas this review provides platform for the researchers to develop an acoustic panel made of NFRC by additive manufacturing and to investigate its acoustical properties.

\section{Additive Manufacturing of Polymers}

Additive manufacturing started its journey with the use of pure polymers. Polymers are made up of many numbers of small molecules called monomers. Monomers combine to form polymers by the process called polymerization. Polymers are classified based on their occurrence, thermal response, physical properties, and mode of formation and also based on online structures [45], which are shown in Figure 1 . There are many polymers like polyester, polypropylene $(\mathrm{PP})$, polyurethane (PU), polyethylene (PE), polystyrene, and polycarbonate that can be used as the matrix in the composite which will be covered under the above classifications. However, only few polymers make their way into the additive manufacturing process because the working temperature of FDM is around $300^{\circ} \mathrm{C}$ which makes only some of the thermoplastic polymers and other polymers to find their way in to the additive manufacturing process [2]. Thermoplastic polymers are those that can be molded above the threshold temperature and returns to the solid state upon cooling [46]. Some of the examples for thermoplastic polymers are acrylonitrile buta-styrene (ABS), polyethylene, polypropylene, polystyrene, polyvinyl chloride, nylon, acrylic, and Teflon. Moreover, the other main reasons are that thermoplastic polymers are not detached during the entire $3 \mathrm{D}$ printing process, whereas the other types of polymers are not suited [47]. There are two sources of polymers which can be used in 3D printing filaments. First, they are from recycled plastics. Example: poly(lactic acid) and acrylonitrile butadiene styrene. Secondary, they are from bioplastics. Example: PLA and polyhydroxyalkonates (PHA). Table 4 shows the list of commonly used polymers used as filaments in FDM technology.

The petroleum-based polymers get out of selection as they increase the carbon footprint value of the product [49]. PHA and PLA are the only bio-based polymers, where the production cost of PHA is higher [50] and the production cost of PLA is very lower [51]. Ivey et al. experimented on extrusion additive manufacturing with carbon fiber-reinforced PLA filaments, and he found that PLA holds good for the extrusion additive manufacturing process for the fiber content of $15 \%$. Mechanical properties of the fiber-reinforced filament were observed to be higher than pure PLA filaments [52]. Rodriquez et al. produces specimens using ABS and PLA by FDM additive manufacturing and found specimens made using PLA exhibits good rigidity, increased tensile strength, and strong bonds between layers of PLA and concluded that PLA is most suitable for the additive manufacturing process [53].

PLA is synthesized from raw materials like rice, corn, and sugar beets and is considered as one of the thermoplastic aliphatic polyesters. PLA has good renewability and compatibility compared to the other biodegradable polymer materials [54]. PLA as a polymer matrix has one of the unique characteristics of being nontoxic [55]. PLA as a polymer matrix with natural fibers as a reinforcement proved out to be most economical and efficient system that can be used widely for many applications [56]. PLA is a one of the best ecofriendly polymers which shows a higher rate of degradation when it is filled in lands and requires lesser energy for production. Global warming caused by bioplastics is negligible compared to conventional plastics [57]. PLA as material itself shows zero carbon footprint, but during the process of PLA, its carbon emission is comparatively little higher than other polymers. But as a whole, carbon footprint of PLA is less compared to all polymers [49]. PLA filaments which are used can be recycled and reused with the certain amount of strength are left behind [58]. Table 5 shows the properties of PLA.

However, there are certain drawbacks that have been registered to the usage of pure polymers like PLA mainly the innate brittleness and low impact strength 
TABLE 3: Some of the research studies on 3D printing of the natural filler composites and its discussion.

\begin{tabular}{|c|c|c|c|c|}
\hline Polymer & Natural fillers & Discussion & $\begin{array}{l}\text { Void (pore, crack, or gap) } \\
\text { formation }\end{array}$ & Reference \\
\hline PLA & Hemp and harakeke & $\begin{array}{c}\text { 3D printing of the natural fibers has been } \\
\text { initiated }\end{array}$ & Yes & {$[28]$} \\
\hline PLA & Bamboo and flax & $\begin{array}{c}\text { The length over diameter ratio of the fibers has } \\
\text { been investigated }\end{array}$ & Yes & {$[31]$} \\
\hline PLA & Wood & $\begin{array}{c}\text { Effect of printing layer thickness on the water } \\
\text { absorption and mechanical properties is } \\
\text { investigated }\end{array}$ & Yes & {$[32]$} \\
\hline PLA & Wood & $\begin{array}{c}\text { Physical and mechanical properties of the } \\
\text { filaments were studied varying the wood } \\
\text { content }\end{array}$ & Yes & {$[33]$} \\
\hline PLA & Aspen wood flour & $\begin{array}{c}\text { Adding } 5 \% \text { wood content to the polymer does } \\
\text { not change the melting temperature of the } \\
\text { composite }\end{array}$ & Yes & {$[34]$} \\
\hline PLA & Pine lignin & $\begin{array}{l}\text { Phase morphology and the mechanical } \\
\text { properties of the printed material were } \\
\text { studied }\end{array}$ & Yes & {$[35]$} \\
\hline PLA & $\begin{array}{l}\text { Thermomechanical pulp } \\
\text { (TMP) }\end{array}$ & $\begin{array}{l}\text { Water absorption and mechanical properties } \\
\text { of the composite were investigated }\end{array}$ & Yes & {$[36]$} \\
\hline PLA & Sugarcane & $\begin{array}{l}\text { Effect of printing orientation on mechanical } \\
\text { properties of the composite was studied }\end{array}$ & Yes & [37] \\
\hline PHB & Sawmill & $\begin{array}{l}\text { Warping of the composite with respect to } \\
\text { addition of fillers was investigated }\end{array}$ & Yes & {$[38]$} \\
\hline Polyethylene & Thermomechanical pulp & $\begin{array}{l}\text { Polyethylene-based filament for AM has been } \\
\text { initiated }\end{array}$ & Yes & [39] \\
\hline ABS & Rice straw & $\begin{array}{l}\text { Water absorption and mechanical properties } \\
\text { of the composite were studied }\end{array}$ & Yes & {$[40]$} \\
\hline ABS & Macadamia nutshells & $\begin{array}{c}\text { Mechanical properties of the composite were } \\
\text { studied }\end{array}$ & Yes & {$[41]$} \\
\hline Polypropylene & Hemp and harakeke & $\begin{array}{l}\text { This study was conducted to check the } \\
\text { potentiality of natural fiber-reinforced } \\
\text { polypropylene filaments }\end{array}$ & Yes & {$[42]$} \\
\hline bioPE & TMP & $\begin{array}{c}\text { Mechanical properties of the composite were } \\
\text { studied }\end{array}$ & Yes & {$[43]$} \\
\hline Polyurethane & Wood flour & $\begin{array}{l}\text { Rheological and mechanical properties of the } \\
\text { composite were discussed }\end{array}$ & Yes & {$[44]$} \\
\hline
\end{tabular}

of the PLA [60]. Fibers are reinforced with polymers to overcome the above issue and can be used for many applications mainly for its high strength, cost reduction, and lighter weight [61].

\section{Natural Fibers as Reinforcement}

There are mainly two types of fibers used as reinforcements in the composite, namely, synthetic fibers such as glass fibers, aramid fibers, carbon fibers, quartz, boron, ceramic fibers, and natural fibers. Natural fibers are obtained from animals, minerals, and plants. Natural fibers are one of the highly used reinforcements in the composites as they are capable of producing higher specific strength and stiffness than other materials [62]. Plant natural fibers which have cellulose as one of its main constituents are broadly classified into 7 categories, and they are bast natural fiber, leaf natural fiber, fruit natural fiber, seed natural fiber, wood natural fiber, stalk natural fiber, and grass natural fiber [63]. The classification and subclassification of natural fibers are shown in Figure 2. Plant-based natural fibers are produced by two types of plants, and they are primary plants and secondary plants. Primary plants get their names because they are primarily grown for producing fibers. Some of the examples of primary plants are sisal, cotton, kenaf, and hemp. In the case of secondary plants, fibers are obtained from the plants as a by-product. Some of the examples of secondary plants are oil palm, coconut coir, banana, and pineapple [64]. Out of all the available fibers that can be used as reinforcements, natural fibers are one of the most suitable materials which can be used in the production of biodegradable and light-weighted composites. These composites are being used in the field of automobiles, electrical, railways, and storage devices [65]. Natural fibers are available in abundant and are biodegradable [66]. Table 6 shows the availability of natural fiber across the world.

Synthetic fibers like glass, carbon, and aramids exhibit better mechanical properties compared to natural fibers. Table 7 provides the mechanical properties of the natural and synthetic fibers comparatively.

Even though synthetic fibers possess higher mechanical properties than natural fibers, natural fibers are being renewable and are eco-friendly [68]. On the overall basis, 


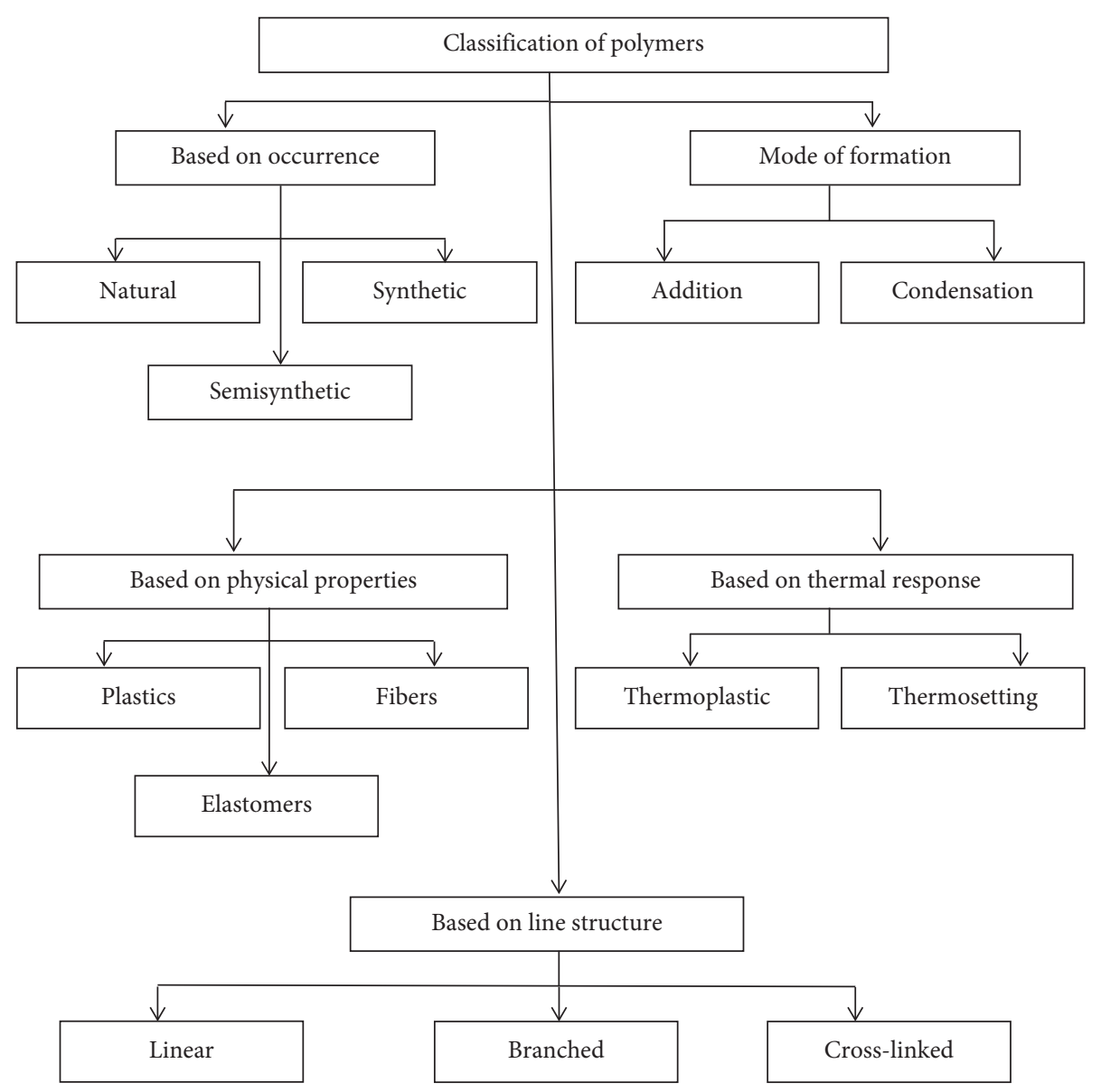

Figure 1: Classification of polymers [45].

TABle 4: List of commonly used polymers as filaments in FDM [48].

\begin{tabular}{lcc}
\hline Polymers & Source & Advantages \\
\hline ABS & Petroleum & Cheap and light weight \\
PET & Petroleum & Recyclable and odorless \\
PLA & Starch, sugar cane & Bio plastic, biodegradable, nontoxic, and odorless \\
PVA & Petroleum & Nontoxic and biodegradable \\
PA & Synthetic fibers & Light weight and water resistance \\
PHA & Sugar & U-V stable \\
\hline
\end{tabular}

TABle 5: Properties of PLA [59].

\begin{tabular}{lcc}
\hline Properties & INGEO 2003D & ASTM standard \\
\hline Tensile strength $(\mathrm{MPa})$ & 52 & D882 \\
Tensile modulus $(\mathrm{GPa})$ & 3.4 & $\mathrm{D} 882$ \\
Tensile yield strength $(\mathrm{MPa})$ & 61 & $\mathrm{D} 882$ \\
Specific gravity & 1.21 & D792 \\
\hline
\end{tabular}

natural fibers exhibit many of the positives like they can produce less weighted composites; they are biodegradable, available in abundant and are economical [65]. This makes them to be suitable material in the part of composites as reinforcement. Table 8 shows the price comparison between natural fibers and synthetic fibers.

Regarding the acoustical properties, natural fibers like kapok exhibit better acoustical absorption than glass wool [69]. Comparison of acoustic absorption coefficient of natural fibers and synthetic fibers is shown in Table 9. Table 10 shows the mechanical properties of all available natural fibers.

It can be seen that natural fibers like hemp, kenaf, and coconut exhibit better acoustic absorption than synthetic fibers.

Natural fibers from banana, bamboo, jute [81], kapok [82], milkweed [83], softwood [84], hardwood [85], rice husk, sugarcane [17], wheat straw [86], and corn husk [87] exhibit good acoustical properties and are used for applications like sound boards, automobiles, and thermal and acoustic panels. Acoustic absorption coefficient (acoustical property) values of the available natural fibers are listed in Table 11.

Hence, from Table 11, it can be concluded that natural fibers can be used as reinforcements in composites which will be used for acoustical applications. 


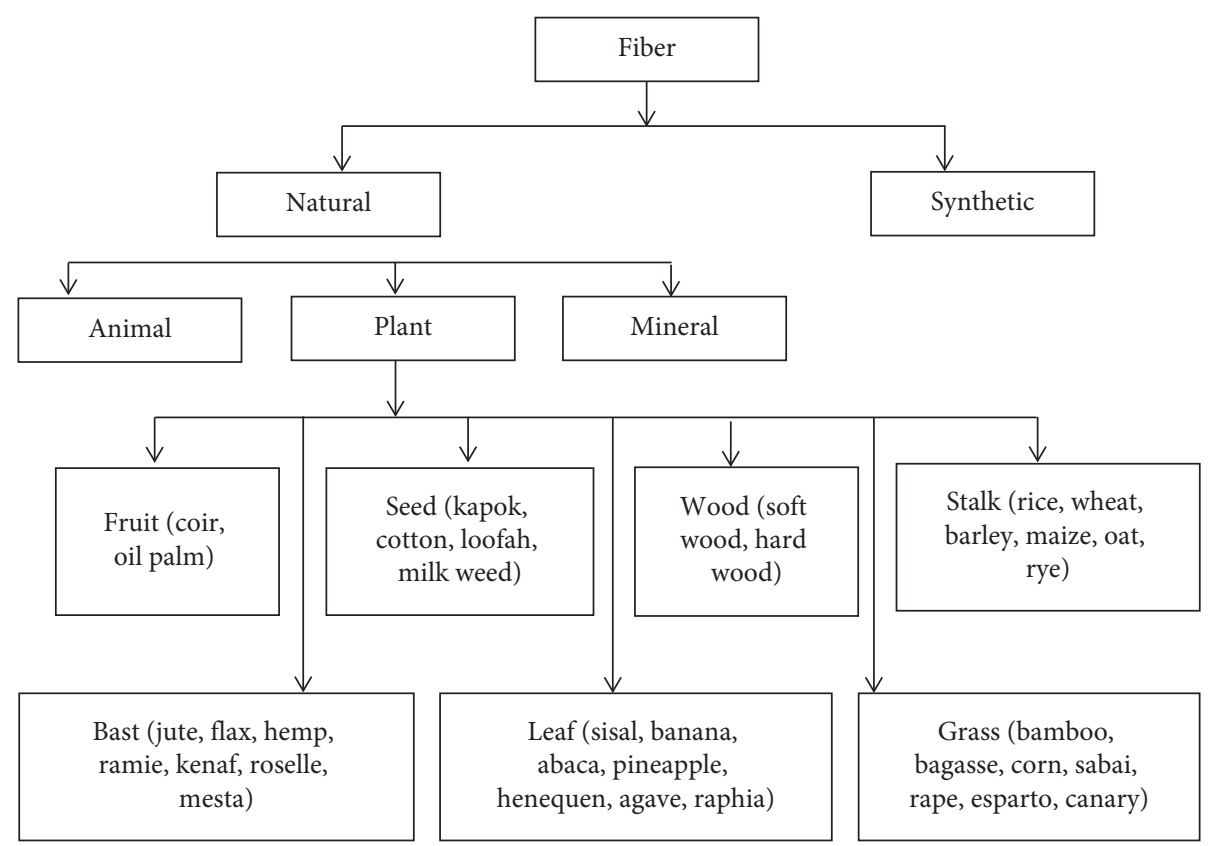

FIgURE 2: Classification and subclassification of natural fibers [63].

TABle 6: Availability of natural fibers [66].

\begin{tabular}{lcc}
\hline Fiber & Source & World production $\left(10^{3}\right.$ tons $)$ \\
\hline Coir & Stem & 100 \\
Oil palm & Fruit & Abundant \\
Flax & Stem & 800 \\
Kenaf & Stem & 760 \\
Jute & Stem & 2,600 \\
Ramie & Stem & 110 \\
Hemp & Stem & 210 \\
Roselle & Stem & 250 \\
Sisal & Stem & 370 \\
Banana & Fruit & 210 \\
Abaca & Stem & 70 \\
Pineapple & Leaf & Abundant \\
Cotton & Stem & 18,550 \\
Wood & Stem & $1,755,020$ \\
Rice & Stem & Abundant \\
Wheat & Stem & Abundant \\
Bamboo & Stem & 10,000 \\
Bagasse & Stem & 75,000 \\
\hline
\end{tabular}

TABLE 7: Mechanical properties of natural and synthetic fibers comparatively [67].

\begin{tabular}{lccc}
\hline Fibers & Density $\left(\mathrm{g} / \mathrm{cm}^{3}\right)$ & Tensile strength $(\mathrm{MPa})$ & Young's modulus $(\mathrm{GPa})$ \\
\hline Carbon & 1.4 & 4000 & $23.0-40.0$ \\
Aramid & 1.4 & $3000-3200$ & $63.0-66.0$ \\
S-Glass & 2.5 & 4500 & 85 \\
Coir & 1.2 & $150-250$ & $3.0-6.0$ \\
Jute & 1.4 & $390-750$ & $12-32$ \\
Hemp & 1.45 & $500-1000$ & 65 \\
\hline
\end{tabular}

Reinforcing synthetic fibers with PLA as a polymer matrix in the composite has drastically increased the mechanical properties of the composite [92]. Considering the cost and environmental impacts, reinforcing natural fibers with various polymer matrices such as polypropylene, polyester, epoxy matrix, and polyethylene is becoming a trend [67]. In Malaysia, natural fibers like coconut coir, coconut husk, oil palm, and paddy are available in 
TABLE 8: Comparison of price between natural and synthetic fibers [8].

\begin{tabular}{lr}
\hline Fibers & Cost in US\$/ton \\
\hline Coir & 350 \\
Abaca & 340 \\
Kenaf & 400 \\
Glass fiber & $1,250-1,750$ \\
Carbon fiber & 12,000 \\
\hline
\end{tabular}

TABLE 9: Comparison of acoustic absorption coefficients between natural and synthetic fibers [70].

\begin{tabular}{|c|c|c|c|c|c|}
\hline \multirow{2}{*}{ Fibers } & \multirow{2}{*}{ Thickness (mm) } & \multicolumn{4}{|c|}{ Absorption coefficient } \\
\hline & & $250 \mathrm{~Hz}$ & $500 \mathrm{~Hz}$ & $1000 \mathrm{~Hz}$ & $2000 \mathrm{~Hz}$ \\
\hline Rock wool & 50 & 0.29 & 0.52 & 0.83 & 0.91 \\
\hline Glass wool & 50 & 0.45 & 0.65 & 0.75 & 0.80 \\
\hline Polyurethane & 50 & 0.30 & 0.68 & 0.89 & 0.79 \\
\hline Polystyrene & 50 & 0.22 & 0.42 & 0.78 & 0.65 \\
\hline Kenaf & 50 & 0.48 & 0.74 & 0.91 & 0.86 \\
\hline Hemp & 40 & 0.59 & 0.60 & 0.56 & 0.52 \\
\hline Coconut & 35 & 0.28 & 0.40 & 0.64 & 0.74 \\
\hline
\end{tabular}

TABLE 10: Mechanical properties of natural fibers.

\begin{tabular}{|c|c|c|c|c|c|}
\hline Fibers & Type & Density $\left(\mathrm{g} / \mathrm{cm}^{3}\right)$ & Tensile strength (MPa) & Young's modulus (GPa) & References \\
\hline Coir & Fruit & 1.2 & $150-200$ & $3.0-6.0$ & [62] \\
\hline Oil palm & Fruit & $0.7-1.5$ & 250 & 3.1 & {$[62]$} \\
\hline Flax & Bast & 1.35 & $350-1050$ & 28 & {$[62]$} \\
\hline Kenaf & Bast & 1.2 & $290-950$ & 50 & {$[62]$} \\
\hline Jute & Bast & 1.23 & $180-775$ & $12-28$ & {$[62]$} \\
\hline Ramie & Bast & 1.44 & $400-950$ & $60-120$ & {$[62]$} \\
\hline Hemp & Bast & 1.35 & $550-1100$ & $65-75$ & {$[62]$} \\
\hline Roselle & Bast & $0.75-0.8$ & $300-850$ & $25-60$ & [71] \\
\hline Sisal & Leaf & 1.2 & $500-800$ & $9.0-23$ & {$[62]$} \\
\hline Banana & Leaf & 1.35 & $520-920$ & $8-35$ & {$[62]$} \\
\hline Abaca & Leaf & 1.5 & 12 & 41 & {$[72]$} \\
\hline Pineapple & Leaf & 1.52 & $410-1625$ & $34-85$ & {$[66]$} \\
\hline Agave & Leaf & 1.36 & 385 & - & {$[73]$} \\
\hline Raphia & Leaf & 1.53 & $152-270$ & - & [74] \\
\hline Kapok & Seed & 0.38 & 90-95 & 4 & {$[72]$} \\
\hline Cotton & Seed & 1.55 & $300-700$ & $5-10$ & [72] \\
\hline Loofah sponge & Seed & $0.3-0.65$ & 11.2 & 1.32 & [75] \\
\hline Milk weed & Seed & 0.97 & $280-380$ & $8.2-9.2$ & [76] \\
\hline Soft wood & Wood & 1.5 & 1050 & 40 & {$[62]$} \\
\hline Hard wood & Wood & 1.2 & 1000 & 38 & {$[62]$} \\
\hline Rice & Stalk & 1.65 & 450 & 1.2 & {$[62]$} \\
\hline Wheat & Stalk & 1.6 & 275 & $4.5-6.5$ & {$[62]$} \\
\hline Barley & Stalk & - & - & $0.3-0.6$ & [77] \\
\hline Maize & Stalk & - & $12-100$ & $1-20$ & {$[78]$} \\
\hline Bamboo & Grass & $0.8-1.4$ & $390-1100$ & $10-30$ & {$[62]$} \\
\hline Bagasse & Grass & 1.2 & 20-300 & - & {$[62]$} \\
\hline Corn & Grass & 0.344 & $160-175$ & $4.5-5.1$ & {$[18]$} \\
\hline Sabai & Grass & - & 76 & - & [79] \\
\hline Esparto & Grass & $1.3-2.1$ & $18-28(\mathrm{cN} / \mathrm{tex})$ & - & [80] \\
\hline
\end{tabular}

abundance. These natural fibers are mainly used for energy harvesting, and most of them are generally disposed in land, causing land problems [93]. Hence, it encourages many of the researchers to utilize these natural fibers as reinforcement in the composite rather than getting disposed. There are many natural fibers available, and each exhibits different properties. There is a differentiation in properties of fibers because of their differences in shape, length, density, and weight. Property of the natural fibers is also defined by the content of cellulose it contains [67]. Thus, selection of fiber is one of the important factors to be considered as it is responsible for the increase in tensile strength, impact strength, hardness, toughness, and also the acoustical property of the composite. Adding to that, selecting the 
TABLE 11: Acoustical absorption coefficient of natural fibers.

\begin{tabular}{lcccc}
\hline Fibers & Fiber properties & Frequency $(\mathrm{Hz})$ & Absorption coefficient $(\alpha)$ & References \\
\hline Coir & Thickness, $35 \mathrm{~mm}$ & 500 & 0.84 & 0.90 \\
Oil palm & Thickness, $50 \mathrm{~mm}$ & 1000 & 0.40 & 0.74 \\
Flax & Diameter, $21.8 \mu \mathrm{m}$ & 500 & 0.20 & {$[70]$} \\
Kenaf & Thickness, $50 \mathrm{~mm}$ & 500 & 0.60 & {$[88]$} \\
Jute & Diameter, $81.2 \mu \mathrm{m}$ & 500 & 0.60 & {$[70]$} \\
Ramie & Thickness, $40 \mathrm{~mm}$ & 800 & 0.10 & {$[89]$} \\
Hemp & Thickness, $40 \mathrm{~mm}$ & 500 & 0.50 & {$[90]$} \\
Sisal & Diameter, $213 \mu \mathrm{m}$ & 500 & 0.13 & {$[70]$} \\
Cotton & Diameter, $13.5 \mu \mathrm{m}$ & 500 & 0.16 & {$[89]$} \\
Bagasse & Thickness, $20 \mathrm{~mm}$ & 500 & 500 & {$[91]$} \\
Corn & Thickness, $20 \mathrm{~mm}$ & & {$[91]$} \\
\hline
\end{tabular}

physical properties like the fiber diameter, layer thickness, and bulk density for developing an acoustic panel has to be considered as these are responsible for effective absorption [94]. Prominent enhancement in the mechanical properties has been reported when reinforcements are done. Daniel et al. reinforced the kenaf fiber with PLA as a matrix and concluded that $30 \%$ fiber content shows the maximum sound absorption coefficient of 0.987 at a frequency of $1521 \mathrm{~Hz}$ and increase in mechanical properties as well [14]. All the available natural fibers reinforced with some of the polymer matrix and their resulting enhanced mechanical and acoustical properties are tabulated in Tables 12 and 13.

Some of the commercially available natural fiber-PLAbased reinforced filaments in the AM process are tabulated in Table 14, and some of the bio-based PLA filaments in AM which are in research stages are tabulated in Table 15. Figure 3 shows the overall list of materials used in FDM technology.

\section{Methodology to Develop an Acoustic Panel Using Natural Fiber-Reinforced Composite}

The methodology to develop an acoustic panel includes the following procedures: (i) compounding the polymer matrix with reinforcement. Melt blending and extrusion are the most common compounding techniques in this recent era; (ii) production of filament; and (iii) developing an acoustic panel by additive manufacturing. Figure 4 shows the novel method to develop an acoustic panel using natural fiberreinforced composite.

\subsection{Techniques for Compounding Polymer Matrix with Reinforcement}

6.1.1. Melt Blending. There are many types of techniques available which are used for producing PLA polymer composites. Some of the techniques which are commonly used are injection molding, transfer molding, and compression molding [136]. These techniques use moldings as a main tool by which researchers can produce the polymer composites. There are also techniques which are used in compounding the reinforcement into the polymer matrix without the moldings. Out of all the available techniques, melt blending is one of the easier and environmental friendly techniques for producing polymer composites [137]. Ibrahim et al. experimented with kenaf fibers as reinforcement in PLA as a polymer matrix by the melt blending technique [138]. Hao et al. melt-blended PLA as a polymer matrix with sisal fibers as a reinforcement and epoxy as a binder and concluded that the composite exhibits improved interfacial bonding [139]. Composites with enhanced mechanical properties are produced by the melt blending technique [61]. There are mainly two types of mixers by which melt blending is performed, and they are internal mixers (e.g., Brabender mixer and Banbury mixer) and continuous mixer (e.g., Buss kneader) [140]. Haramen et al. melt-blended PLA as a polymer matrix with oil palm empty fruit bunch fiber using Brabender internal mixer, and the composite shows promising mechanical properties by adding plasticizer [141]. Daniel et al. melt-blended PLA as a polymer matrix with kenaf fibers using Brabender internal mixer, and the composite with different compositions is tested for both mechanical and acoustical properties [14]. The temperature for the process can be maintained between $180^{\circ} \mathrm{C}$ and $190^{\circ} \mathrm{C}$ considering the melting temperature of pure PLA [138]. The rotor speed of the mixer can be selected as $50 \mathrm{rpm}$ as it exhibits high intensity of mixing and maximum shear rate [140].

6.1.2. Extrusion. Extrusion is defined as the process of imposing the material into the die under various conditions to achieve the required product [142]. Extrusion is widely used in many of the applications, and they are used in food industry, pharmaceutical industry, plastic industry, and rubber industry [143]. Extrusion, on allowing the researchers to define the parameters like rotating speed, residence time, and temperature, is being responsible for good dispersion of fibers and orientation of fibers, thereby influencing the properties of the composite [144]. Steuernagel reinforced natural fibers with polymer composites using the extrusion technique and concluded that there is a good dispersion of fibers in the matrix [145]. Gamon et al. compounded natural fibers from bamboo and miscanthus with PLA as a polymer matrix using the extrusion technique [146]. Also, extrusion is considered one of the most economical processes with a lesser processing time. Some of the advantages of extrusion techniques are as follows; extrudes show uniform content, and fine particles 
TABLE 12: Natural fibers with various polymer matrices and their resulting enhancement in mechanical properties.

\begin{tabular}{|c|c|c|c|}
\hline Fibers & Polymer matrix & Enhancement in properties & References \\
\hline Coir & PLA & $\begin{array}{l}\text { The impact strength of the matrix is increased by } 28 \% \\
\text { at } 3 \% \text { fiber content. }\end{array}$ & {$[95]$} \\
\hline Oil palm & PLA & $\begin{array}{l}\text { The impact strength and tensile strength of the matrix } \\
\text { are increased by } 2 \% \text { and } 5 \% \text {, respectively, at } 30 \% \text { fiber } \\
\text { content. }\end{array}$ & {$[96]$} \\
\hline Jute & PLA & $\begin{array}{l}\text { The tensile strength and stiffness of the matrix are } \\
\text { almost doubled at } 40 \% \text { fiber content. }\end{array}$ & {$[97]$} \\
\hline Flax & PLA & $\begin{array}{l}\text { There is an increase in tensile stress of the matrix by } \\
5.6 \% \text { at } 30 \% \text { fiber weight. }\end{array}$ & {$[98]$} \\
\hline Hemp & PLA & $\begin{array}{l}\text { There is an increase in } 21.5 \% \text { of tensile strength of the } \\
\text { matrix at } 40 \% \text { fiber content. }\end{array}$ & [99] \\
\hline Ramie & PLA & $\begin{array}{l}\text { The } 30 \% \text { fiber content shows increase in mechanical } \\
\text { properties than the matrix. }\end{array}$ & {$[100]$} \\
\hline Kenaf & PLA & $\begin{array}{c}\text { There is } 85.4 \% \text { increase in tensile strength of the } \\
\text { matrix at } 70 \% \text { fiber weight. }\end{array}$ & {$[101]$} \\
\hline Sisal & PLA & $\begin{array}{c}\text { There is an increase in tensile strength of the } \\
\text { composite by } 34.7 \% \text { at } 30 \% \text { short fiber weight than } \\
\text { long fiber. }\end{array}$ & [102] \\
\hline Banana & PLA & $\begin{array}{l}\text { Tensile strength of the composite almost increases by } \\
15.11 \% \text { than that of matrix at } 20 \% \text { fiber content. }\end{array}$ & {$[103]$} \\
\hline Abaca & PLA & $\begin{array}{l}\text { There is an increase in tensile strength and impact } \\
\text { strength by } 14.8 \% \text { and } 58.4 \% \text { at } 30 \% \text { fiber content. }\end{array}$ & {$[104]$} \\
\hline Pineapple & PLA & $\begin{array}{l}\text { Tensile strength of the composite almost doubles at } \\
50 \% \text { fiber weight than the pure PLA. }\end{array}$ & [105] \\
\hline Agave & PLA & $\begin{array}{l}\text { At } 40 \% \text { fiber content, impact strength of the } \\
\text { composite increases by } 71 \% \text {. }\end{array}$ & [106] \\
\hline Cotton & PLA & $\begin{array}{c}\text { There is an increase in tensile strength and impact } \\
\text { strength of the composite by } 26.8 \% \text { and } 24.1 \% \text {, } \\
\text { respectively, at } 40 \% \text { fiber content. }\end{array}$ & {$[107]$} \\
\hline Loofah & PLA & $\begin{array}{c}\text { Tensile strength and impact strength of the composite } \\
\text { increases by } 16.5 \% \text { and } 19.6 \% \text {, respectively, at } 2 \% \\
\text { fiber weight. }\end{array}$ & {$[108]$} \\
\hline Milk weed & PLA & $\begin{array}{l}\text { Tensile strength of milkweed/PLA composite was } \\
\text { found to be } 48.1 \mathrm{MPa} \text { at } 8 \% \text { fiber content which is } \\
\text { greater than the pure PLA. }\end{array}$ & [109] \\
\hline Wood & PLA & $\begin{array}{c}\text { Impact and tensile of the composite increases by } \\
\text { nearly } 7.8 \% \text { and } 0.36 \% \text { at } 20 \% \text { and } 40 \% \text { wood flour } \\
\text { content. }\end{array}$ & [110] \\
\hline Rice & PLA & $\begin{array}{l}\text { There is an increase in flexural modulus by } 15 \% \text { at } \\
20 \% \text { rice husk content. }\end{array}$ & [111] \\
\hline Wheat & PLA & $\begin{array}{l}\text { Tensile modulus of the composite increased at } 30 \% \\
\text { wheat straw content. Maleated PLA was used as a } \\
\text { compatibilizer to enhance the tensile and flexural } \\
\text { strength. }\end{array}$ & [112] \\
\hline Oat & PLA-PP & $\begin{array}{l}\text { Improved storage modulus of the composite was } \\
\text { recorded at } 30 \% \text { fiber content. }\end{array}$ & [113] \\
\hline Rye & PLA & $\begin{array}{l}\text { The tensile and impact strength of PLA-rye } \\
\text { composite is almost doubled when compared with } \\
\text { PP-rye composite. }\end{array}$ & [114] \\
\hline Bamboo & PLA & $\begin{array}{l}\text { Impact strength of the composite almost doubled } \\
\text { when medium bamboo fibers are used at } 40 \% \text { fiber } \\
\text { content. }\end{array}$ & [115] \\
\hline Corn & PLA & $\begin{array}{l}\text { There is an increase in tensile strength of the } \\
\text { composite by almost } 21.7 \% \text { at } 1 \% \text { fiber content. } \\
\text { Flexural and elastic modulus of the composite }\end{array}$ & [116] \\
\hline Sugarcane & PLA & $\begin{array}{c}\text { increases by } 25.5 \% \text { and } 8.97 \% \text { at } 30 \% \text { fiber content, } \\
\text { respectively. }\end{array}$ & [117] \\
\hline Mesta & PLA & $\begin{array}{l}\text { There is a satisfied increase in tensile strength of the } \\
\text { composite. Flexural strength of the composite was } \\
\text { increased by } 25 \% \text { at } 50 \% \text { fiber content. }\end{array}$ & [118] \\
\hline
\end{tabular}


TABle 12: Continued.

\begin{tabular}{|c|c|c|c|}
\hline Fibers & Polymer matrix & Enhancement in properties & References \\
\hline Esparto & PLA & $\begin{array}{l}\text { Reinforcement at fiber content up to } 40 \% \text { fiber } \\
\text { content shows superior mechanical and thermal } \\
\text { properties. }\end{array}$ & [119] \\
\hline Rape & TPS & $\begin{array}{l}\text { Tensile strength of the composite increases by } 95 \% \\
\text { when rapeseed fibers are reinforced. }\end{array}$ & [120] \\
\hline Canary & Epoxy & $\begin{array}{l}\text { Various adhesives and pretreatment method have } \\
\text { been followed. Out of all, canary with epoxy provides } \\
\text { better mechanical properties. }\end{array}$ & [121] \\
\hline Roselle & $\mathrm{RF}$ & $\begin{array}{l}\text { Tensile strength and flexural strength of the } \\
\text { composite increases by } 62 \% \text { for short fibers at } 1: 1.5 \\
\text { ratio of resin. }\end{array}$ & [122] \\
\hline Raphia & Polyester & $\begin{array}{l}\text { At } 20 \% \text { fiber loading, microhardness of the composite } \\
\text { increases by about } 11.67 \% \text { than the matrix. }\end{array}$ & {$[123]$} \\
\hline Kapok & Polyester & $\begin{array}{c}\text { In case of kapok hybrid composite, impact strength is } \\
\text { increased by } 65.2 \% \text { at } 50 \% \text { kapok fabric and } 50 \% \\
\text { glass. }\end{array}$ & {$[124]$} \\
\hline Barley & $\mathrm{PP}$ & $\begin{array}{l}\text { At } 40 \% \text { fiber content, barley composite shows } \\
\text { improved tensile and impact strength than coconut } \\
\text { and wood fiber. }\end{array}$ & [125] \\
\hline Maize & PCL & $\begin{array}{l}\text { Tensile strength of the composite almost increases by } \\
\qquad 78 \% \text { at } 66 \% \text { fiber content. }\end{array}$ & [126] \\
\hline Sabai & Sand & $\begin{array}{l}\text { At } 1 \% \text { fiber content, sabai fiber composite shows good } \\
\text { benefits. }\end{array}$ & {$[127]$} \\
\hline
\end{tabular}

TABLE 13: Natural fibers with various polymer matrices and their resulting enhancement in acoustical properties.

\begin{tabular}{|c|c|c|c|}
\hline Fibers & Polymer matrix & Enhancement in properties & References \\
\hline Kenaf & PLA & $\begin{array}{c}\text { Acoustic absorption coefficient was recorded as } 0.987 \\
\text { at the frequency of } 1521.02 \mathrm{~Hz} \text { for } 30 \% \text { fiber content. } \\
\text { At } 50 \% \text { fiber content, the maximum acoustic }\end{array}$ & {$[14]$} \\
\hline Jute & $\mathrm{PP}$ & $\begin{array}{c}\text { absorption coefficient was } 0.175 \text { at the frequency of } \\
1250 .\end{array}$ & {$[81]$} \\
\hline Kapok & Polyester & $\begin{array}{l}\text { Acoustic absorption coefficient was peaked to } 0.83 \text { at } \\
2500 \mathrm{~Hz} \text { for } 90 \% \text { fiber content. }\end{array}$ & {$[82]$} \\
\hline Flax & Epoxy & $\begin{array}{l}\text { Flax/epoxy composites show better acoustical } \\
\text { absorption than glass/epoxy composites. }\end{array}$ & {$[128]$} \\
\hline Banana & $\mathrm{PP}$ & $\begin{array}{l}\text { Acoustic absorption coefficient was recorded as } 0.13 \\
\text { at a frequency of } 1250 \mathrm{~Hz} \text { for } 50 \% \text { fiber content. }\end{array}$ & {$[81]$} \\
\hline Bamboo & PP & $\begin{array}{c}\text { For } 50 \% \text { fiber content, acoustic absorption coefficient } \\
\text { was } 0.2 \text { at a frequency of } 1250 \mathrm{~Hz} \text {. }\end{array}$ & {$[81]$} \\
\hline Tea leaf & PU & $\begin{array}{l}24 \% \text { fiber content of tea fibers provides best acoustic } \\
\text { absorption of } 0.75 \text { in midfrequency ranges. }\end{array}$ & [129] \\
\hline Wood & Polyester & $\begin{array}{c}\text { The peak acoustic absorption was } 0.97 \text { at a frequency } \\
\text { of } 4660 \mathrm{~Hz} \text { at } 3: 1 \text { fiber to matrix ratio. }\end{array}$ & {$[130]$} \\
\hline Wood & $\mathrm{PE}$ & $\begin{array}{l}\text { Maximum sound absorption was observed from } \\
2000 \mathrm{~Hz} \text { onwards. }\end{array}$ & [131] \\
\hline Kenaf and rice straw & PP & $\begin{array}{c}\text { Kenaf/PP composites show better acoustic absorption } \\
\text { than rice/PP composites. }\end{array}$ & [132] \\
\hline Kenaf, coir, ijuk, oil palm & Natural rubber & $\begin{array}{c}\text { Acoustic absorption coefficient is peak for kenaf at } \\
700 \mathrm{~Hz}-800 \mathrm{~Hz} \text {, coir at } 1000 \mathrm{~Hz}-1075 \mathrm{~Hz} \text {, oil palm at } \\
850 \mathrm{~Hz}-1200 \mathrm{~Hz} \text {, and ijuk at } 3200 \mathrm{~Hz}-3400 \mathrm{~Hz} \text {. }\end{array}$ & [133] \\
\hline
\end{tabular}

TABLe 14: Commercially available PLA-based filaments [134].

\begin{tabular}{lcc}
\hline Fibers/materials & Polymer & Company \\
\hline Pine/wood fill & PLA & ColorFabb, NL \\
Bamboo/bamboo fill & PLA & ColorFabb, NL \\
Straw plastic/dried crop residues & PLA & Jinghe co., CN \\
Laywoo/cherrywood & PLA & CC products, DE \\
\hline
\end{tabular}

which are added as additives are uniformly distributed [143].

There are mainly three types of extruders available, and they are screw extruders, roller-type extruders, and piston extruders. Out of all the three types of extruders, screw extruders are one of the most commonly used extruders in recent times. Screw extruders are categorized as single screw 
TABLE 15: Available bio-based polymer filaments.

\begin{tabular}{lcc}
\hline Fibers/materials & Polymer & References \\
\hline Dried distilled grains & PLA & {$[134]$} \\
Paulownia wood & PLA & {$[134]$} \\
Osage orange wood & PLA & {$[134]$} \\
Kraft lignin & PLA & {$[35]$} \\
Oil palm fiber & HDPE & {$[27]$} \\
Cotton & LDPE & {$[135]$} \\
Thermomechanical pulp & PE & {$[39]$} \\
Hemp & PLA & {$[28]$} \\
Harakeke & PLA & {$[28]$} \\
\hline
\end{tabular}

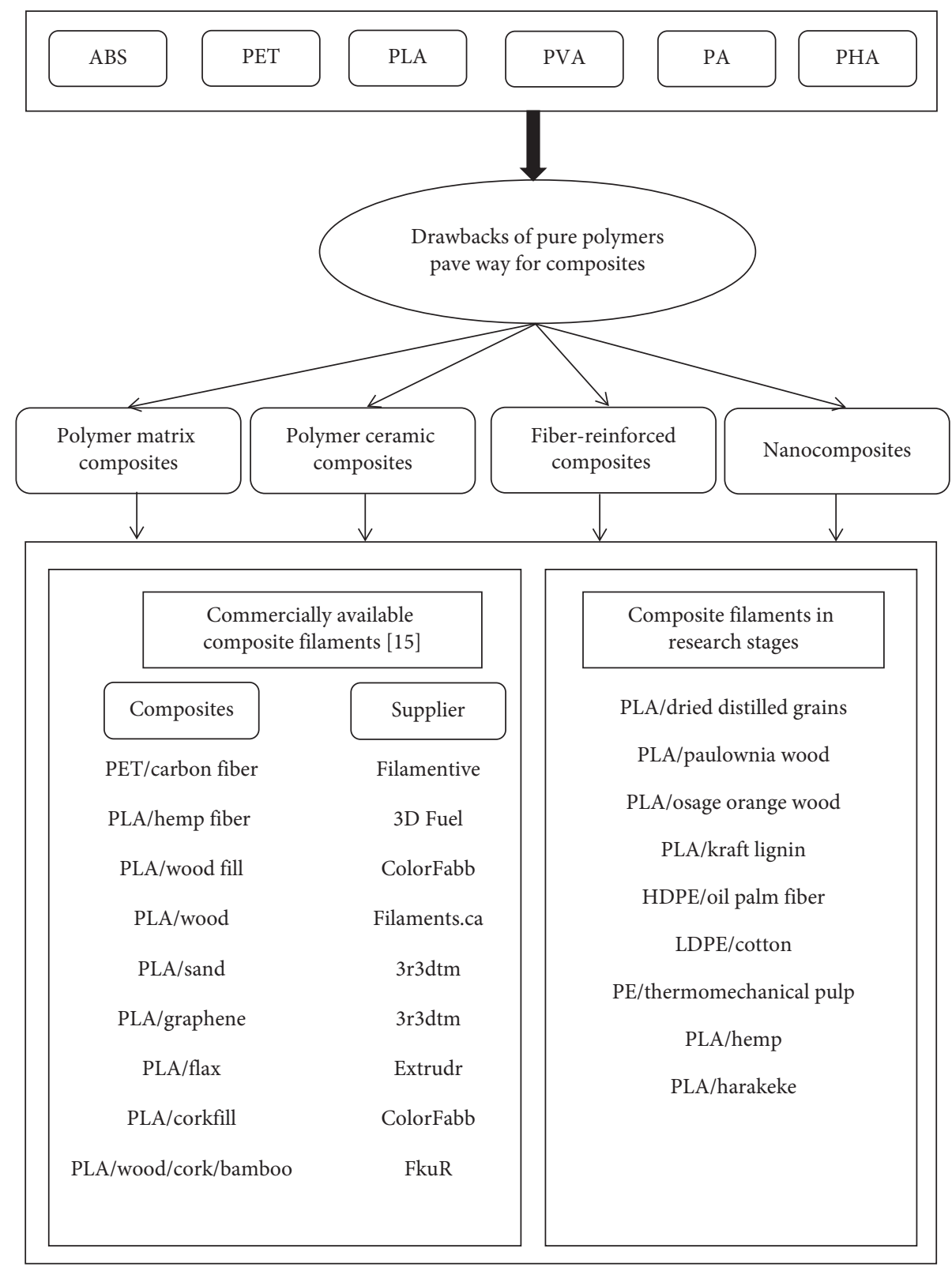

FIgURE 3: Overall list of materials used in FDM technology.

and twin screw extruder [142]. Table 16 shows the difference between single screw and twin screw extruder. The temperature of the extrusion process can be maintained at $180^{\circ} \mathrm{C}$ to $190^{\circ} \mathrm{C}$ considering the melting temperature of pure PLA [148].
6.2. Filaments for Additive Manufacturing. Filaments are produced by melting the polymers and extruding it to the spinneret to convert the melted polymer into solidified filaments. This process is called spinning. There are 


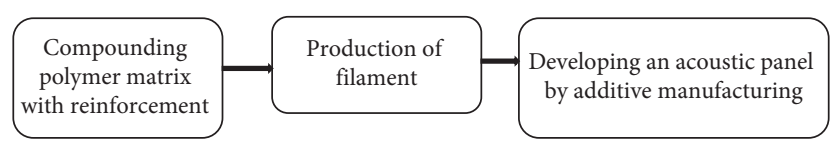

FIgURE 4: Novel method to develop an acoustic panel using natural fiber-reinforced composite.

TABLE 16: Difference between single screw and twin screw extruder [147].

\begin{tabular}{lcc}
\hline Parameters & Single screw & Twin screw \\
\hline Consumption of power $(\mathrm{kJ} / \mathrm{kg})$ & 910 to 1520 & 410 to 620 \\
Distribution of heat & Temperature difference is larger & Temperature difference is smaller \\
Rigidity & High & Low \\
Dissipation of power & Larger shear force & Smaller shear force \\
Cost & Low & High \\
Degasification & Simple & Complex \\
Water content $(\%)$ & 12 to 35 & 10 to 96 \\
\hline
\end{tabular}

mainly four types of techniques for producing filaments, and they are dry spinning, wet spinning, melt spinning, and gel spinning. Dry spinning and wet spinning are used when polymers need to be dissolved in solvents [149]. There are many natural fiber-reinforced polymer filaments available commercially, and also some are in research stages.

6.3. Additive Manufacturing Process. There will be problems like uneven finish during 3D printing of NFRC [28] which can be sorted out by optimizing its process and product parameters. Process parameters (nozzle diameter, filament diameter, printing speed, melting temperature, infill geometry, infill thickness, number of layers, and thickness of layers), product parameters (fiber geometry, fiber content, treatment of fiber, and fiber morphology), and environmental conditions like humidity of the fiber will be responsible for the mechanical and acoustical properties of the panel. Recent review article by Mazzanti et al. covered the product and process parameters that influences the mechanical properties of the 3D printed NFRC [29], whereas effect of product and process parameters on the acoustical properties of the $3 \mathrm{D}$ printed NFRC has to be investigated further. However, review article by Mamtaz et al. covered some of the properties like the fiber size, bulk density of the fiber, and sample layer thickness in order to obtain optimum acoustic absorption especially at lower frequency spectrums [150]. Parameters like porosity, tortuosity, flow resistivity, thermal characteristic length, and viscous characteristic length have to be optimized for effective sound absorption as these parameters influence acoustic absorption [151]. Moreover, perforation ratio should be considered as one of the important factors in designing an acoustic absorbing device for its effective absorption [152]. In general, natural fibers and NFRC experience few drawbacks such as they are vulnerable to microbial growth [153], have lower mechanical properties [134], and provides poor resistance to heat and flames [154]. These drawbacks are expected to be addressed when the NFRC are mixed with additives [155].

\section{Carbon Footprint and Its Impact}

Earlier, developing a product itself was made as one of the greatest achievements. But, in recent times, developing a product which has lesser environmental impacts is coming into business. Adding to that, carbon footprint of the product is one of the highly noted topics in this modern era. Carbon footprint value of the product has created a high background because it is directly impacting the climatic changes. Natural products and their biomass are providing good support to all countries in terms of economy. At the same time, the emissions of carbon into the atmosphere are also growing proportionally which is not a good sign. This increase in carbon footprint is having a negative impact on the climatic changes [156], thereby affecting the natural vegetation of the country. Carbon footprint of a product can be evaluated and optimized by life cycle assessment (LCA) [157]. LCA has two life cycles of the product: Business-to-Customer (B2C) and Businessto-Business (B2B). B2C estimates the emission of a product from raw material to disposal, whereas B2B estimates the emission till the development of product. Value of carbon footprint is negligible in biopolymers when compared to other polymers [11]. There are varieties of polymers used in producing biocomposite filaments for the additive manufacturing process. PLA as a polymer shows zero carbon footprint, whereas polymers like PE, PP, and PET show a higher carbon emission [49]. Moreover, processing of PLA also produces lesser carbon emissions as its processing stages involve lesser electricity and take energy from renewable sources [158]. Surprisingly, biopolymer composites show higher carbon footprint value than petroleum-based composites when there are lots of wastage occurred and produced during the process of manufacturing a product [159]. Therefore, it is necessary to minimize the wastages during the manufacturing process. If the biocomposites are managed properly, they will offer good carbon savings [160]. Some of the biocomposites and their percentage of carbon savings are listed in Table 17. 
TABLE 17: Biocomposites with their percentage of carbon savings [160].

\begin{tabular}{lc}
\hline Biocomposites (BCs) & Carbon savings (\%) \\
\hline Hemp fiber BC & $10-50$ \\
Kenaf fiber BC & $9.2-10.7$ \\
Cellulose fiber BC & $16.3-18.7$ \\
Cotton fiber BC & 40 \\
\hline
\end{tabular}

\section{Conclusion}

This review paper opens up additive manufacturing as a novel method for developing an acoustic panel with enhanced mechanical and acoustical properties using natural fiber-reinforced composites. Poly(lactic acid) is the trending polymer that can be selected as a polymer matrix which is biodegradable, nontoxic, recyclable, and eco-friendly. Natural fibers as reinforcement can be selected based on the requirements and availability. Composites can be produced by suitable compounding techniques and converted into filaments using suitable spinning techniques. The natural fiber-reinforced filament can be 3D-printed into an acoustic panel using FDM technology. The 3D-printed composites will have minor voids formation between deposition lines. This void formation can be turned as a favor since acoustic panel need small range of pores to absorb sound effectively. The outcome of this approach will be an acoustic panel made of natural fiber-reinforced composites which will be replacing the synthetic fiber based-acoustic panels. This approach will ensure the positivity towards attributes like cost, environmental impact, and sustainability.

\section{Conflicts of Interest}

The authors declare that there are no conflicts of interest regarding the publication of this paper.

\section{Acknowledgments}

This work was partially sponsored by Taylor's University Flagship Research Grant TUFR/2017/001/05. The author is thankful to the Taylor's University for funding scholarship during the course of this research work.

\section{References}

[1] T. D. Ngo, A. Kashani, G. Imbalzano, K. T. Q. Nguyen, and D. Hui, "Additive manufacturing (3D printing): a review of materials, methods, applications and challenges," Composites Part B: Engineering, vol. 143, pp. 172-196, 2018.

[2] N. Mohan, P. Senthil, S. Vinodh, and N. Jayanth, "A review on composite materials and process parameters optimisation for the fused deposition modelling process," Virtual and Physical Prototyping, vol. 12, no. 1, pp. 47-59, 2017.

[3] K. V. Wong and A. Hernandez, "A review of additive manufacturing," International Scholarly Research Network (ISRN) Mechanical Engineering, vol. 2012, Article ID 208760, 10 pages, 2012.

[4] X. Wang, M. Jiang, Z. Zhou, J. Gou, and D. Hui, “3D printing of polymer matrix composites: a review and prospective," Composites Part B: Engineering, vol. 110, pp. 442-458, 2017.
[5] H. L. Tekinalp, V. Kunc, G. M. Velez-Garcia et al., "Highly oriented carbon fiber-polymer composites via additive manufacturing," Composites Science and Technology, vol. 105, pp. 144-150, 2014.

[6] Z. Liu, J. Zhan, M. Fard, and J. L. Davy, "Acoustic properties of multilayer sound absorbers with a $3 \mathrm{D}$ printed microperforated panel," Applied Acoustics, vol. 121, pp. 25-32, 2017.

[7] V. Mirón, S. Ferrándiz, D. Juárez, and A. Mengual, "Manufacturing and characterization of 3D printer filament using tailoring materials," Procedia Manufacturing, vol. 13, pp. 888-894, 2017.

[8] P. Peças, H. Carvalho, H. Salman, and M. Leite, "Natural fibre composites and their applications: a review," Journal of Composites Science, vol. 2, no. 4, p. 66, 2018.

[9] "Kulim carbon footprint report," Kulim (Malaysia) Berhad, Johor Bahru, Malaysia, 2016.

[10] F. Meng, S. J. Pickering, and J. McKechnie, "An environmental comparison of carbon fibre composite waste end-oflife options," in Proceedings of the SAMPE Europe Conference 2018, Southampton, UK, September 2018.

[11] B. Choi, S. Yoo, and S. Il Park, "Carbon footprint of packaging films made from LDPE, PLA, and PLA/PBAT blends in South Korea," Sustainability, vol. 10, no. 7, 2018.

[12] H. Mamtaz, M. Hosseini Fouladi, S. Narayana Namasivayam et al., "Novel implementation of natural fibro-granular materials as acoustic absorbers," Noise and Vibration Worldwide, vol. 49, no. 9-10, pp. 311-316, 2018.

[13] U. Berardi and G. Iannace, "Acoustic characterization of natural fibers for sound absorption applications," Building and Environment, vol. 94, pp. 840-852, 2015.

[14] D. D. V. S. Chin, M. N. B. Yahya, N. B. C. Din, and P. Ong, "Acoustic properties of biodegradable composite microperforated panel (BC-MPP) made from kenaf fi bre and polylactic acid (PLA)," Applied Acoustics, vol. 138, pp. 179$187,2018$.

[15] M. Hosseini Fouladi, M. J. M. Nor, M. Ayub, and Z. A. Leman, "Utilization of coir fiber in multilayer acoustic absorption panel," Applied Acoustics, vol. 71, no. 3, pp. 241-249, 2010.

[16] P. V. Bansod, T. S. Teja, and A. R. Mohanty, "Improvement of the sound absorption performance of jute felt-based sound absorbers using micro-perforated panels," Journal of Low Frequency Noise, Vibration and Active Control, vol. 36, no. 4, pp. 376-398, 2017.

[17] F. Zuhaira, I. Mohamad, N. Rahmat, and N. M. Ishak, "A study on absorption coefficient of sustainable acoustic panels from rice husks and sugarcane baggase," Advanced Materials Research, vol. 1113, pp. 198-203, 2015.

[18] N. H. Sari, I. N. G. Wardana, Y. S. Irawan, and E. Siswanto, "Physical and acoustical properties of corn husk fiber panels," Advances in Acoustics and Vibration, vol. 2016, Article ID 5971814, 8 pages, 2016.

[19] Z. A. Rachman, S. S. Utami, J. Sarwono, R. Widyorini, and H. R. Hapsari, "The usage of natural materials for the green acoustic panels based on the coconut fibers and the citric acid solutions," Journal of Physics: Conference Series, vol. 1075, p. 12048, 2018.

[20] J. Kang and M. W. Brocklesby, "Feasibility of applying micro-perforated absorbers in acoustic window systems," Applied Acoustics, vol. 66, no. 6, pp. 669-689, 2005.

[21] G. Iannace, A. Trematerra, and P. Trematerra, "Acoustic correction using green material in classrooms located in historical buildings," Acoustics Australia, vol. 41, no. 3, 2013. 
[22] M. Kaamin, N. S. M. Mahir, A. A. Kadir, N. B. Hamid, M. Mokhtar, and N. Ngadiman, "Sound absorption study on acoustic panel from kapok fiber and egg tray," Advanced Materials for Sustainability and Growth AIP Conference Proceedings, vol. 1901, article 130012, 2017.

[23] C. W. Chou, R. P. Lai, S. Chien, and P. H. Yeh, "Development and sound absorption of interior adjustable acoustical panels," in Proceedings of the Internoise 2014, Melbourne, Australia, November 2014.

[24] R. del Rey, J. Alba, J. Rodríguez, and L. Bertó, "Characterization of new sustainable acoustic solutions in a reduced sized transmission chamber," Buildings, vol. 9, no. 3, p. 60, 2019.

[25] G. D. Goh, Y. L. Yap, S. Agarwala, and W. Y. Yeong, "Recent progress in additive manufacturing of fiber reinforced polymer composite," Advanced Materials Technologies, vol. 4, no. 1, 2019.

[26] W. Zhong, F. Li, Z. Zhang, L. Song, and Z. Li, "Short fiber reinforced composites for fused deposition modeling," Materials Science and Engineering: A, vol. 301, no. 2, pp. 125-130, 2001.

[27] O. M. F. Marwah, N. F. A. Halim, M. S. Shukri, E. J. Mohamad, and M. Ibrahim, "A study on palm fiber reinforces as a filament in portable FDM," ARPN Journal of Engineering and Applied Sciences, vol. 11, no. 12, pp. 78287834, 2016.

[28] D. Stoof and K. Pickering, "Fused deposition modelling of natural fibre/polylactic acid composites," Journal of Composites Science, vol. 1, no. 1, p. 8, 2017.

[29] V. Mazzanti, L. Malagutti, and F. Mollica, "FDM 3D printing of polymers containing natural Fillers: a review of their mechanical properties," Polymers, vol. 11, no. 7, p. 1094, 2019.

[30] D. B. Pedersen, G. Tosello, and H. N. Hansen, "State-of-theart of fiber-reinforced polymers in additive manufacturing technologies," Journal of Reinforced Plastics and Composites, vol. 36, no. 15, pp. 1061-1073, 2017.

[31] D. Depuydt, M. Balthazar, K. Hendrickx et al., "Production and characterization of bamboo and flax fiber reinforced polylactic acid filaments for fused deposition modeling (FDM)," Polymer Composites, vol. 40, no. 5, pp. 1951-1963, 2019.

[32] N. Ayrilmis, M. Kariz, J. H. Kwon, and M. Kitek Kuzman, "Effect of printing layer thickness on water absorption and mechanical properties of 3D-printed wood/PLA composite materials," The International Journal of Advanced Manufacturing Technology, vol. 102, no. 5-8, pp. 2195-2200, 2019.

[33] M. Kariz, M. Sernek, M. Obućina, and M. K. Kuzman, "Effect of wood content in FDM filament on properties of 3D printed parts," Materials Today Communications, vol. 14, pp. 135-140, 2018.

[34] Y. Tao, H. Wang, Z. Li, P. Li, and S. Q. Shi, "Development and application of wood flour-filled polylactic acid composite filament for 3d printing," Materials, vol. 10, no. 4, p. 339, 2017.

[35] E. Gkartzou, E. P. Koumoulos, and C. A. Charitidis, "Production and 3D printing processing of bio-based thermoplastic filament," Manufacturing Review, vol. 4, p. 1, 2017.

[36] D. Filgueira, S. Holmen, J. K. Melbø, D. Moldes, A. T. Echtermeyer, and G. Chinga-Carrasco, "Enzymaticassisted modification of thermomechanical pulp fibers to improve the interfacial adhesion with poly(lactic acid) for 3D printing," ACS Sustainable Chemistry and Engineering, vol. 5, no. 10, pp. 9338-9346, 2017.

[37] H. Liu, H. He, X. Peng, B. Huang, and J. Li, “Three-dimensional printing of poly(lactic acid) bio-based composites with sugarcane bagasse fiber: effect of printing orientation on tensile performance," Polymers for Advanced Technologies, vol. 30, no. 4, pp. 910-922, 2019.

[38] A. A. Vaidya, C. Collet, M. Gaugler, and G. Lloyd-Jones, "Integrating softwood biorefinery lignin into polyhydroxybutyrate composites and application in 3D printing," Materials Today Communications, vol. 19, pp. 286-296, 2019.

[39] D. Filgueira, S. Holmen, J. K. Melbø, D. Moldes, A. T. Echtermeyer, and G. Chinga-Carrasco, "3D printable filaments made of biobased polyethylene biocomposites," Polymers, vol. 10, no. 3, p. 314, 2018.

[40] M. A. Osman and M. R. A. Atia, "Investigation of ABS-rice straw composite feedstock filament for FDM," Rapid Prototyping Journal, vol. 24, no. 6, pp. 1067-1075, 2018.

[41] J. Girdis, L. Gaudion, G. Proust, S. Löschke, and A. Dong, "Rethinking timber: investigation into the use of waste macadamia nut shells for additive manufacturing," JOM, vol. 69, no. 3, pp. 575-579, 2017.

[42] M. Milosevic, D. Stoof, and K. L. Pickering, "Characterizing the mechanical properties of fused deposition modelling natural fiber recycled polypropylene composites," Journal of Composites Science, vol. 1, no. 1, p. 7, 2017.

[43] Q. Tarrés, J. K. Melbø, M. Delgado-Aguilar, F. X. Espinach, P. Mutjé, and G. Chinga-Carrasco, "Bio-polyethylene reinforced with thermomechanical pulp fibers: mechanical and micromechanical characterization and its application in 3Dprinting by fused deposition modelling," Composites Part B: Engineering, vol. 153, pp. 70-77, 2018.

[44] H. Bi, Z. Ren, R. Guo, M. Xu, and Y. Song, "Fabrication of flexible wood flour/thermoplastic polyurethane elastomer composites using fused deposition molding," Industrial Crops and Products, vol. 122, pp. 76-84, 2018.

[45] S. Tomar, L. Singh, and V. Sharma, "Miraculous adjuvants: the pharmaceutical polymers," International Research Journal of Pharmacy, vol. 7, no. 7, pp. 10-18, 2016.

[46] A. Pucci, "Smart and modern thermoplastic polymer materials," Polymers, vol. 10, no. 11, pp. 10-12, 2018.

[47] S. H. Kochesfahani, "Improving PLA-based material for FDM 3d-printers using minerals (principles and method development)," in Proceedings of the Society of Plastics Engineers Annual Technical Conference, pp. 1958-1614, Indianapolis, IN, USA, May 2016.

[48] N. Bentzen and E. Laussen, "Using Recycled and Bio-Based Plastics for Additive Manufacturing," Master's thesis in product development, Department of Industrial and Materials Science, Division of Product Development, Chalmers University of Technology, Gothenburg, Sweden, 2018.

[49] R. Narayan, "Carbon footprint of bioplastics using biocarbon content analysis and life-cycle assessment," MRS Bulletin, vol. 36, pp. 716-721, 2011.

[50] J. Możejko-Ciesielska and R. Kiewisz, "Bacterial polyhydroxyalkanoates: still fabulous?," Microbiological Research, vol. 192, pp. 271-282, 2016.

[51] O. Avinc and A. Khoddami, "Overview of poly (lactic acid) (PLA) fiber Part I: production, properties, performance, environmental impact and end-use applications of poly (lactic acid) fibres," Fibre Chemistry, vol. 41, no. 6, pp. 16-25, 2009.

[52] M. Ivey, G. W. Melenka, J. P. Carey, and C. Ayranci, "Characterizing short-fiber-reinforced composites produced 
using additive manufacturing," Advanced Manufacturing: Polymer \& Composites Science, vol. 3, no. 3, pp. 81-91, 2017.

[53] A. Rodríguez-Panes, J. Claver, and A. M. Camacho, "The influence of manufacturing parameters on the mechanical behaviour of PLA and ABS pieces manufactured by FDM: a comparative analysis," Materials, vol. 11, no. 8, 2018.

[54] R. A. Abd Alsaheb, A. Aladdin, N. Z. Othman et al., "Recent applications of polylactic acid in pharmaceutical and medical industries," Journal of Chemical and Pharmaceutical Research, vol. 7, no. 12, pp. 51-63, 2015.

[55] C. Gonçalves, I. C. Gonçalves, F. D. Magalhães, and A. M. Pinto, "Poly(lactic acid) composites containing carbon-based nanomaterials: a review," Polymers, vol. 9, no. 12, p. 269, 2017.

[56] Y. Zhao, J. Qiu, H. Feng, M. Zhang, L. Lei, and X. Wu, "Improvement of tensile and thermal properties of poly(lactic acid) composites with admicellar-treated rice straw fiber," Chemical Engineering Journal, vol. 173, no. 2, pp. 659-666, 2011.

[57] F. Gironi and V. Piemonte, "Bioplastics and petroleumbased plastics: strengths and weaknesses," Energy Sources, Part A: Recovery, Utilization, and Environmental Effects, vol. 33, no. 21, pp. 1949-1959, 2011.

[58] R. S. Babagowda, K. Math, R. Goutham, and K. R. Srinivas Prasad, "Study of effects on mechanical properties of PLA filament which is blended with recycled PLA materials," IOP Conference Series: Materials Science and Engineering, vol. $310,2018$.

[59] T. F. Cipriano, A. L. N. Silva, A. H. M. F. T. Silva, A. M. F. Sousa, G. M. Silva, and M. C. G. Rocha, "Thermal, rheological and morphological properties of poly (lactic acid) (PLA) and talc composites," Polímeros, vol. 24, no. 3, pp. 276-282, 2014.

[60] F. Daver, K. P. M. Lee, M. Brandt, and R. Shanks, "Cork-PLA composite filaments for fused deposition modelling," Composites Science and Technology, vol. 168, pp. 230-237, 2018.

[61] T. G. Y. Gowda, M. R. Sanjay, K. S. Bhat, P. Madhu, P. Senthamaraikannan, and B. Yogesha, "Polymer matrixnatural fiber composites: an overview," Cogent Engineering, vol. 5, no. 1, 2018.

[62] S. R. Djafari Petroudy, "Physical and mechanical properties of natural fibers," Advanced High Strength Natural Fibre Composites in Construction, pp. 59-83, 2017.

[63] N. Saba, P. Tahir, and M. Jawaid, "A review on potentiality of Nano filler/natural fiber filled polymer hybrid composites," Polymers, vol. 6, no. 8, pp. 2247-2273, 2014.

[64] S. Debnath, C. W. Nguong, and S. N. B. Lee, "A review on natural fibre reinforced polymer composites," World Academy of Science, Engineering and Technology, vol. 73, pp. 1123-1130, 2013.

[65] C. Elanchezhian, B. V. Ramnath, G. Ramakrishnan, M. Rajendrakumar, V. Naveenkumar, and M. K. Saravanakumar, "Review on mechanical properties of natural fiber composites," Materials Today: Proceedings, vol. 5, no. 1, pp. 1785-1790, 2018.

[66] M. Asim, K. Abdan, M. Jawaid et al., "A review on pineapple leaves fibre and its composites," International Journal of Polymer Science, vol. 2015, Article ID 950567, 16 pages, 2015.

[67] R. Siakeng, M. Jawaid, H. Ariffin, S. M. Sapuan, M. Asim, and N. Saba, "Natural fiber reinforced polylactic acid composites: a review," Polymer Composites, vol. 40, no. 2, pp. 446-463, 2019.

[68] M. R. Sanjay, G. R. Arpitha, L. L. Naik, K. Gopalakrishna, and B. Yogesha, "Applications of natural fibers and its composites: an overview," Natural Resources, vol. 7, no. 3, pp. 108-114, 2016.

[69] H.-f. Xiang, D. Wang, H.-c. Liua, N. Zhao, and J. Xu, "Investigation on sound absorption properties of kapok fibers," Chinese Journal of Polymer Science, vol. 31, no. 3, pp. 521529, 2013.

[70] F. Asdrubali, "Green and sustainable materials for noise control in buildings," in Proceedings of the 19th International Congress on Acoustics, Buenos Aires, Argentina, September 2006.

[71] R. Nadlene, S. M. Sapuan, M. Jawaid, M. R. Ishak, and L. Yusriah, "A review on roselle fiber and its composites," Journal of Natural Fibers, vol. 13, no. 1, pp. 10-41, 2016.

[72] L. Y. Mwaikambo, "Review of the history, properties and application of plant fibres," African Journal of Science and Technology, Science and Engineering Series, vol. 7, no. 2, pp. 120-133, 2006.

[73] S. Msahli, Y. Chaabouni, F. Sakli, and J. Y. Drean, "Mechanical behavior of Agave Americana L. fibres: correlation between fine structure and mechanical properties," Journal of Applied Sciences, vol. 7, no. 24, pp. 3951-3957, 2007.

[74] O. Fadele, I. N. A. Oguocha, A. Odeshi, M. Soleimani, and C. Karunakaran, "Characterization of raffia palm fiber for use in polymer composites," Journal of Wood Science, vol. 64, pp. 650-663, 2018.

[75] J. Shen, Y. Min Xie, X. Huang, S. Zhou, and D. Ruan, "Mechanical properties of luffa sponge," Journal of the Mechanical Behavior of Biomedical Materials, vol. 15, pp. 141-152, 2012.

[76] S. Hassanzadeh and H. Hasani, "A review on milkweed fiber properties as a high-potential raw material in textile applications," Journal of Industrial Textiles, vol. 46, no. 6, pp. 1412-1436, 2017.

[77] H. Tavakoli, S. S. Mohtasebi, and A. Jafari, "Effects of moisture content, internode position and loading rate on the bending characteristics of barley straw," Research in Agricultural Engineering, vol. 55, no. 2, pp. 45-51, 2009.

[78] J. Huang, W. Liu, F. Zhou, Y. Peng, and N. Wang, "Mechanical properties of maize fibre bundles and their contribution to lodging resistance," Biosystems Engineering, vol. 151, pp. 298-307, 2016.

[79] N. Chand and P. K. Rohatgi, "Potential use, mechanical and thermal studies of sabai grass fibre," Journal of Materials Science Letters, vol. 11, no. 9, pp. 578-580, 1992.

[80] L. Ghali, M. Zidi, and S. Roudesli, "Physical and mechanical characterization of technical esparto (alfa) fibres," Journal of Applied Sciences, vol. 6, no. 11, pp. 2450-2455, 2006.

[81] G. Thilagavathi, E. Pradeep, T. Kannaian, and L. Sasikala, "Development of natural fiber nonwovens for application as car interiors for noise control," Journal of Industrial Textiles, vol. 39, no. 3, pp. 267-278, 2010.

[82] X. Liu, X. Yan, L. Li, and H. Zhang, "Sound-absorption properties of kapok fiber nonwoven fabrics at low frequency," Journal of Natural Fibers, vol. 12, no. 4, pp. 311-322, 2015.

[83] P. Ganesan and T. Karthik, "Development of acoustic nonwoven materials from kapok and milkweed fibres," The Journal of The Textile Institute, vol. 107, no. 4, pp. 477-482, 2016.

[84] I. Bre, "Acoustical properties of wood in string instruments soundboards and tuned idiophones: biological and cultural diversity," The Journal of Acoustical Society of america, vol. 131, no. 1, pp. 807-818, 2012. 
[85] L. Karlinasari, H. Baihaqi, A. Maddu, and T. R. Mardikanto, "The acoustical properties of Indonesian hardwood species," Makara Journal of Science, vol. 16, no. 2, pp. 110-114, 2012.

[86] M. C. Kiran, B. S. Mamatha, N. Anand, and V. Prakash, "Acoustic and thermal behavior of low density wheat straw particle board," International Journal of Science and Research, vol. 7, no. 9, pp. 543-547, 2018.

[87] X. Tang, X. Zhang, H. Zhang, X. Zhuang, and X. Yan, “Corn husk for noise reduction: robust acoustic absorption and reduced thickness," Applied Acoustics, vol. 134, pp. 60-68, 2018.

[88] K. H. Or, A. Putra, and M. Z. Selamat, "Oil palm empty fruit bunch fibres as sustainable acoustic absorber," Applied Acoustics, vol. 119, pp. 9-16, 2017.

[89] D. J. Oldham, C. A. Egan, and R. D. Cookson, "Sustainable acoustic absorbers from the biomass," Applied Acoustics, vol. 72, no. 6, pp. 350-363, 2011.

[90] W. Yang and Y. Li, "Sound absorption performance of natural fibers and their composites," Science China Technological Sciences, vol. 55, no. 8, pp. 2278-2283, 2012.

[91] M. H. Fouladi and M. H. Nassir, "Utilizing Malaysian natural fibers as sound absorber," in Intechopen, Chapter 7, pp. 161-170, 2013.

[92] X. Tian, T. Liu, C. Yang, Q. Wang, and D. Li, "Interface and performance of 3D printed continuous carbon fiber reinforced PLA composites," Composites Part A: Applied Science and Manufacturing, vol. 88, pp. 198-205, 2016.

[93] T. A. Tahir and F. S. Hamid, "Vermicomposting of two types of coconut wastes employing Eudrilus eugeniae: a comparative study," International Journal Of Recycling of Organic Waste in Agriculture, vol. 1, no. 1, p. 7, 2012.

[94] M. J. M. Nor, M. Ayub, R. Zulkifli, N. Amin, and M. H. Fouladi, "Effect of different factors on the acoustic absorption of coir fiber," Journal of Applied Sciences, vol. 10, no. 22, pp. 2887-2892, 2010.

[95] Z. Sun, L. Zhang, D. Liang, W. Xiao, and J. Lin, "Mechanical and thermal properties of PLA biocomposites reinforced by coir fibers," International Journal of Polymer Science, vol. 2017, Article ID 2178329, 8 pages, 2017.

[96] M. D. H. Beg, J. O. Akindoyo, S. Ghazali, and A. A. Mamun, "Impact modified oil palm empty fruit bunch fiber/poly (lactic) acid composite," International Journal of Chemical, Nuclear, Materials and Metallurgical Engineering, vol. 9, no. 1, 2015.

[97] D. Plackett, T. Løgstrup Andersen, W. Batsberg Pedersen, and L. Nielsen, "Biodegradable composites based on 1-polylactide and jute fibres," Composites Science and Technology, vol. 63, no. 9, pp. 1287-1296, 2003.

[98] K. Oksman, M. Skrifvars, and J.-F. Selin, "Natural fibres as reinforcement in polylactic acid (PLA) composites," Composites Science and Technology, vol. 63, no. 9, pp. 1317-1324, 2003.

[99] R. Hu and J.-K. Lim, "Fabrication and mechanical properties of completely biodegradable hemp fiber reinforced polylactic acid composites," Journal of Composite Materials, vol. 41, no. 13, pp. 1655-1669, 2007.

[100] T. Yu, Y. Li, and J. Ren, "Preparation and properties of short natural fiber reinforced poly(lactic acid) composites," Transactions of Nonferrous Metals Society of China, vol. 19, pp. s651-s655, 2009.

[101] S. Ochi, "Mechanical properties of kenaf fibers and kenaf/ PLA composites," Mechanics of Materials, vol. 40, no. 4-5, pp. 446-452, 2008.
[102] S. Chaitanya and I. Singh, "Processing of PLA/sisal fiber biocomposites using direct- and extrusion-injection molding," Materials and Manufacturing Processes, vol. 32, no. 5, pp. 468-474, 2017.

[103] Y.-F. Shih and C.-C. Huang, "Polylactic acid (PLA)/banana fiber (BF) biodegradable green composites," Journal of Polymer Research, vol. 18, no. 6, pp. 2335-2340, 2011.

[104] A. K. Bledzki, A. Jaszkiewicz, and D. Scherzer, "Mechanical properties of PLA composites with man-made cellulose and abaca fibres," Composites Part A: Applied Science and Manufacturing, vol. 40, no. 4, pp. 404-412, 2009.

[105] S. Kaewpirom and C. Worrarat, "Preparation and properties of pineapple leaf fiber reinforced poly(lactic acid) green composites," Fibers and Polymers, vol. 15, no. 7, pp. 14691477, 2014.

[106] D. Edén, R. R. G. Denis, E. Omar, C. A. Alejandra, and J. R. Robledo-ortíz, "Polylactic acid - agave fiber biocomposites produced by rotational molding: a comparative study with compression molding," Advances in Polymer Technology, vol. 37, no. 7, pp. 2528-2540, 2017.

[107] N. Graupner, "Application of lignin as natural adhesion promoter in cotton fibre-reinforced poly(lactic acid) (PLA) composites," Journal of Materials Science, vol. 43, no. 15, pp. 5222-5229, 2008.

[108] C. Parida, S. K. Dash, and P. Chaterjee, "Mechanical properties of injection molded poly(lactic) Acid-Luffa fiber composites," Soft Nanoscience Letters, vol. 05, no. 04, pp. $65-72,2015$.

[109] V. L. Finkenstadt, C.-K. Liu, R. Evangelista et al., "Poly(lactic acid) green composites using oilseed coproducts as fillers," Industrial Crops and Products, vol. 26, no. 1, pp. 36-43, 2007.

[110] E. Petinakis, L. Yu, G. Edward, K. Dean, H. Liu, and A. D. Scully, "Effect of matrix-particle interfacial adhesion on the mechanical properties of poly(lactic acid)/wood-flour micro-composites," Journal of Polymers and the Environment, vol. 17, no. 2, pp. 83-94, 2009.

[111] A. A. Yussuf, I. Massoumi, and A. Hassan, "Comparison of polylactic acid/kenaf and polylactic acid/rise husk composites: the influence of the natural fibers on the mechanical, thermal and biodegradability properties," Journal of Polymers and the Environment, vol. 18, no. 3, pp. 422-429, 2010.

[112] C. Nyambo, A. K. Mohanty, and M. Misra, "Effect of maleated compatibilizer on performance of PLA/wheat straw-based green composites," Macromoleular Materials and Engineering, vol. 296, no. 8, pp. 710-718, 2011.

[113] J. P. Reddy, M. Misra, and A. Mohanty, "Injection moulded biocomposites from oat hull and polypropylene/polylactide blend: fabrication and performance evaluation," Advances in Mechanical Engineering, vol. 5, Article ID 761840, 2013.

[114] A. A. Mamun and A. K. Bledzki, "Micro fibre reinforced PLA and PP composites: enzyme modification, mechanical and thermal properties," Composites Science and Technology, vol. 78, pp. 10-17, 2013.

[115] R. Tokoro, D. M. Vu, K. Okubo, T. Tanaka, T. Fujii, and T. Fujiura, "How to improve mechanical properties of polylactic acid with bamboo fibers," Journal of Materials Science, vol. 43, no. 2, pp. 775-787, 2008.

[116] P. Deejam and S. Charuchinda, "Mechanical properties of poly(lactic acid) sheet reinforced with microfibrillated cellulose from corn cobs," MATEC Web of Conferences, vol. 30, p. 3007, 2015.

[117] L. Wang, Z. Tong, L. O. Ingram, Q. Cheng, and S. Matthews, "Green composites of poly (lactic acid) and sugarcane bagasse residues from bio-refinery processes," Journal of 
Polymers and the Environment, vol. 21, no. 3, pp. 780-788, 2013.

[118] B.-H. Lee, H.-S. Kim, S. Lee, H.-J. Kim, and J. R. Dorgan, "Bio-composites of kenaf fibers in polylactide: role of improved interfacial adhesion in the carding process," Composites Science and Technology, vol. 69, no. 15-16, pp. 2573-2579, 2009.

[119] A. Maghchiche, "Characterisation of esparto grass fibers reinforced biodegradable polymer composites," Biosciences Biotechnology Research Asia, vol. 10, no. 2, pp. 665-673, 2013.

[120] E. Espigulé, X. Puigvert, F. Vilaseca, J. A. Méndez, P. Mutjé, and J. Girones, "Thermoplastic starch-based composites reinforced with rape fibers: water uptake and thermomechanical properties," BioResources, vol. 8, no. 2, pp. 2620-2630, 2013.

[121] J. Trischler and D. Sandberg, "Monocotyledons in particleboard Production: adhesives, additives, and surface modification of reed canary grass," BioResources, vol. 9, no. 3, pp. 3919-3938, 2014.

[122] A. S. Singha and V. K. Thakur, "Physical, chemical and mechanical properties of Hibiscus sabdariffa Fiber/polymer composite," International Journal of Polymeric Materials, vol. 58, no. 4, pp. 217-228, 2009.

[123] D. C. Anike, T. U. Onuegbu, I. M. Ogbu, and I. O. Alaekwe, "The effect of alkali treatment on the tensile behaviour and hardness of raffia palm fibre reinforced composites," American Journal of Polymer Science, vol. 4, no. 4, pp. 117-121, 2014.

[124] G. Venkata Reddy and S. Venkata Naidu, "Impact properties of kapok based unsaturated polyester hybrid composites," Journal of Reinforced Plastics and Composites, vol. 27, no. 1617, pp. 1789-1804, 2015.

[125] A. K. Bledzki, A. A. Mamun, and J. Volk, "Barley husk and coconut shell reinforced polypropylene composites: the effect of fibre physical, chemical and surface properties," Composites Science and Technology, vol. 70, no. 5, pp. 840846, 2010.

[126] M. Dauda, M. Yoshiba, K. Miura, and S. Takahashi, "Processing and mechanical property evaluation of maize fiber reinforced green composites," Advanced Composite Materials, vol. 16, no. 4, pp. 335-347, 2007.

[127] J. Maity, B. C. Chattopadhyay, and S. P. Mukherjee, "Behaviour of different types of sand randomly mixing with various natural fibers," Journal of The Institution of Engineers (India): Series A, vol. 93, no. 2, pp. 97-104, 2012.

[128] H. P. Lee, B. M. P. Ng, A. V. Rammohan, and L. Q. N. Tran, "An investigation of the sound absorption properties of flax/ epoxy composites compared with glass/epoxy composites," Journal of Natural Fibers, vol. 14, no. 1, pp. 71-77, 2017.

[129] S. Çelebi and H. Küçük, "Acoustic properties of tea-leaf fiber mixed polyurethane composites," Cellular Polymers, vol. 31, no. 5, pp. 241-256, 2012.

[130] L. Peng, B. Song, J. Wang, and D. Wang, "Mechanic and acoustic properties of the sound-absorbing material made from natural fiber and polyester," Advances in Materials Science and Engineering, vol. 2015, Article ID 274913, 5 pages, 2015.

[131] Z. Daeipour, "Evaluation of the acoustic properties of woodplastic-chalk composites," Engineering, Technology and Applied Science Research, vol. 7, no. 2, pp. 1540-1545, 2017.

[132] E. Jayamani, S. Hamdan, P. Ezhumalai, and S. K. Heng, "Acoustic and thermal properties of polymer composites reinforced with lignocellulosic fibers," Applied Mechanics and Materials, vol. 624, pp. 25-29, 2014.
[133] M. N. Yahya, M. Sambu, H. A. Latif, and T. M. Junaid, "A study of acoustics performance on natural fibre composite," IOP Conference Series: Materials Science and Engineering, vol. 226, p. 012013, 2017.

[134] B. Tisserat, Z. Liu, V. Finkenstadt, B. Lewandowski, S. Ott, and L. Reifschneider, "3D printing biocomposites," Journal of Plastics Research Online 2015 (Society of Plastics Engineers), pp. 1-3, 2015.

[135] A. Kearns, N. Farahbakhsh, R. Venditti, and J. Jur, "Cotton fibers in 3D printing," in Proceedings of the 27th Annual International Solid Freeform Fabrication Symposium-An Additive Manufacturing Conference: Solid Freeform Fabrication 2016, pp. 899-905, Austin, TX, USA, August 2016.

[136] P. K. Bajpai, I. Singh, and J. Madaan, "Development and characterization of PLA-based green composites," Journal of Thermoplastic Composite Materials, vol. 27, no. 1, pp. 52-81, 2014.

[137] N. Ercan, A. Durmus, and A. Kaşgöz, "Comparing of melt blending and solution mixing methods on the physical properties of thermoplastic polyurethane/organoclay nanocomposite films," Journal of Thermoplastic Composite Materials, vol. 30, no. 7, pp. 950-970, 2017.

[138] N. A. Ibrahim, W. M. Zin Wan Yunus, M. Othman, K. Abdan, and K. A. Hadithon, "Poly(Lactic Acid) (PLA)reinforced kenaf bast fiber composites: the effect of triacetin," Journal of Reinforced Plastics and Composites, vol. 29, no. 7, pp. 1099-1111, 2010.

[139] M. Hao, H. Wu, F. Qiu, and X. Wang, "Interface bond improvement of sisal fibre reinforced polylactide composites with added epoxy oligomer," Materials, vol. 11, no. 3, p. 398, 2018.

[140] J. K. Lee and C. D. Han, "Evolution of polymer blend morphology during compounding in an internal mixer," Polymer, vol. 40, no. 23, pp. 6277-6296, 1999.

[141] A. S. Harmaen, A. Khalina, A. R. Faizal, and M. Jawaid, "Effect of triacetin on tensile properties of oil palm empty fruit bunch fiber-reinforced polylactic acid composites," Polymer-Plastics Technology and Engineering, vol. 52, no. 4, pp. 400-406, 2013.

[142] M. S. Alam, J. Kaur, H. Khaira, and K. Gupta, "Extrusion and extruded products: changes in quality attributes as affected by extrusion process parameters: a review," Critical Reviews in Food Science and Nutrition, vol. 56, no. 3, pp. 445-473, 2016.

[143] M. Maniruzzaman, J. S. Boateng, M. J. Snowden, and D. Douroumis, "A review of hot-melt Extrusion: process technology to pharmaceutical products," ISRN Pharmaceutics, vol. 2012, Article ID 436763, 9 pages, 2012.

[144] A. Gallos, G. Paes, F. Allais, and J. Beaugrandbd, "Lignocellulosic fibers: a critical review of the extrusion process for enhancement of the properties of natural fiber composites," RSC Advances, vol. 2017, no. 7, pp. 34638-34654, 2017.

[145] L. Steuernagel and J. Ring, "Natural Fibre/PA6 composites with flame retardance properties: extrusion and characterisation," Composites Part B, vol. 108, pp. 325-333, 2016.

[146] G. Gamon, P. Evon, and L. Rigal, "Twin-screw extrusion impact on natural fibre morphology and material properties in poly(lactic acid) based biocomposites," Industrial Crops and Products, vol. 46, pp. 173-185, 2013.

[147] D. J. Van Zuilichem, W. Stolp, and L. P. B. M. Janssen, "Engineering aspects of single- and twin-screw extrusioncooking of biopolymers," Journal of Food Engineering, vol. 2, no. 3, pp. 157-175, 1983. 
[148] M. S. Z. M. Desa, A. Hassan, and A. Arsad, "The effect of natural rubber toughening on mechanical properties of poly (lactic acid)/multiwalled carbon nanotube nanocomposite," Advanced Materials Research, vol. 747, pp. 639-642, 2013.

[149] R. Alagirusamy and A. Das, "Conversion of fibre to yarn," in Textiles and Fashion, Chapter 8, Part 2, vol. 126, pp. 159-189, 2015.

[150] H. Mamtaz, M. H. Fouladi, M. Al-Atabi, and S. N. Namasivayam, "Acoustic absorption of natural fiber composites," Journal of Engineering, vol. 2016, Article ID 5836107, 11 pages, 2016.

[151] H. Mamtaz, M. Hosseini Fouladi, M. Z. Nuawi, S. Narayana Namasivayam, M. Ghassem, and M. Al-Atabi, "Acoustic absorption of fibro-granular composite with cylindrical grains," Applied Acoustics, vol. 126, pp. 58-67, 2017.

[152] Z. Liu, J. Zhan, M. Fard, and J. L. Davy, "Acoustic measurement of a 3D printed micro-perforated panel combined with a porous material," Measurement, vol. 104, pp. 233-236, 2017.

[153] B. Crawford, S. Pakpour, N. Kazemian et al., "Effect of fungal deterioration on physical and mechanical properties of hemp and flax natural fiber composites," Materials, vol. 10, no. 11, p. 1252, 2017.

[154] N. K. Kim, S. Dutta, and D. Bhattacharyya, "A review of flammability of natural fibre reinforced polymeric composites," Composites Science and Technology, vol. 162, pp. 64-78, 2018.

[155] M. Hosseini Fouladi, M. Ayub, and M. Jailani Mohd Nor, "Analysis of coir fiber acoustical characteristics," Applied Acoustics, vol. 72, no. 1, pp. 35-42, 2011.

[156] P. C. Jain, "Greenhouse effect and climate change: scientific basis and overview," Renewable Energy, vol. 3, no. 4-5, pp. 403-420, 1993.

[157] A. Evandro, C. J. Kibert, J. Woo et al., "The carbon footprint of buildings : a review of methodologies and applications," Renewable and Sustainable Energy Reviews, vol. 94, pp. 1142-1152, 2018.

[158] J. J. Shen, "Comparative life cycle assessment of polylactic acid (PLA) and polyethylene terephthalate (PET)," in Comparative Assessment of PLA and PET, 2011.

[159] J. Boonniteewanich, S. Pitivut, S. Tongjoy, S. Lapnonkawow, and S. Suttiruengwong, "Evaluation of carbon footprint of bioplastic straw compared to petroleum based straw products," Energy Procedia, vol. 56, pp. 518-524, 2014.

[160] J. P. Correa, J. M. Montalvo-Navarrete, and M. A. HidalgoSalazar, "Carbon footprint considerations for biocomposite materials for sustainable products: a review," Journal of Cleaner Production, vol. 208, pp. 785-794, 2019. 


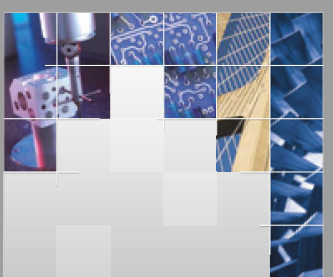

\section{Enfincering}
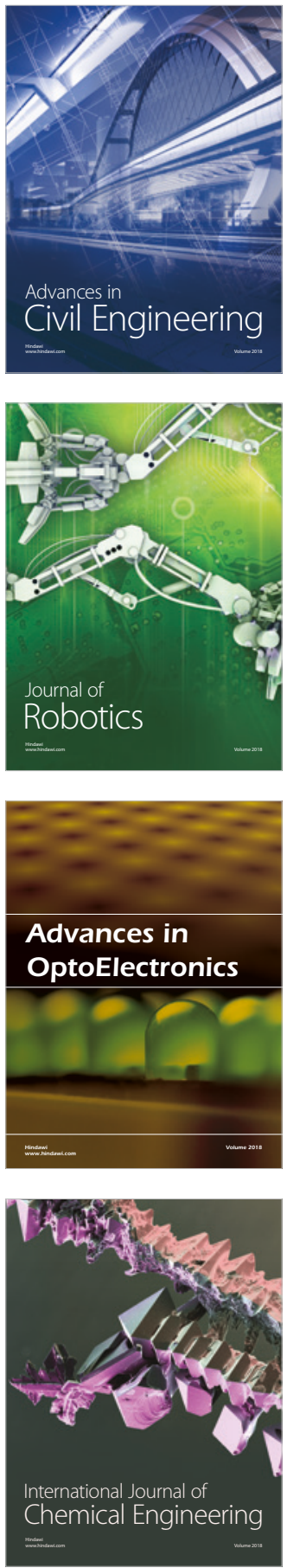

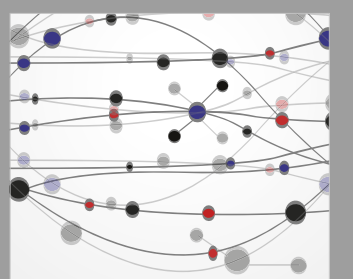

\section{Rotating \\ Machinery}

The Scientific World Journal

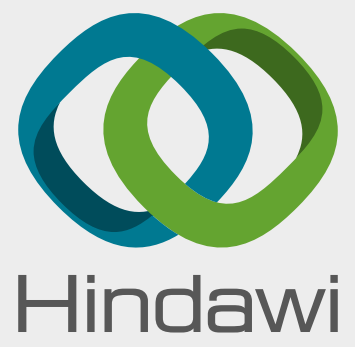

Submit your manuscripts at

www.hindawi.com
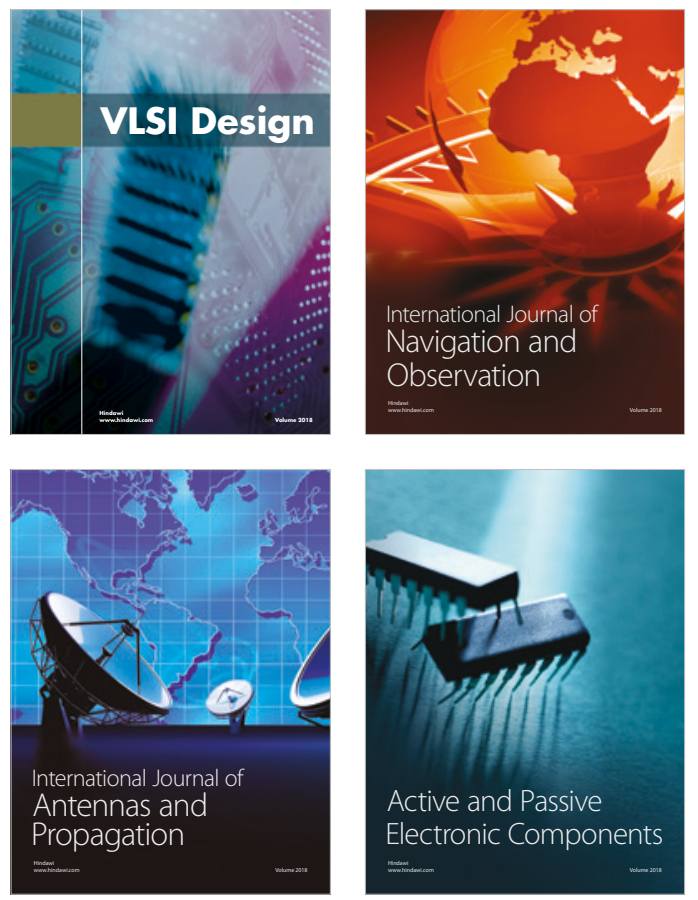
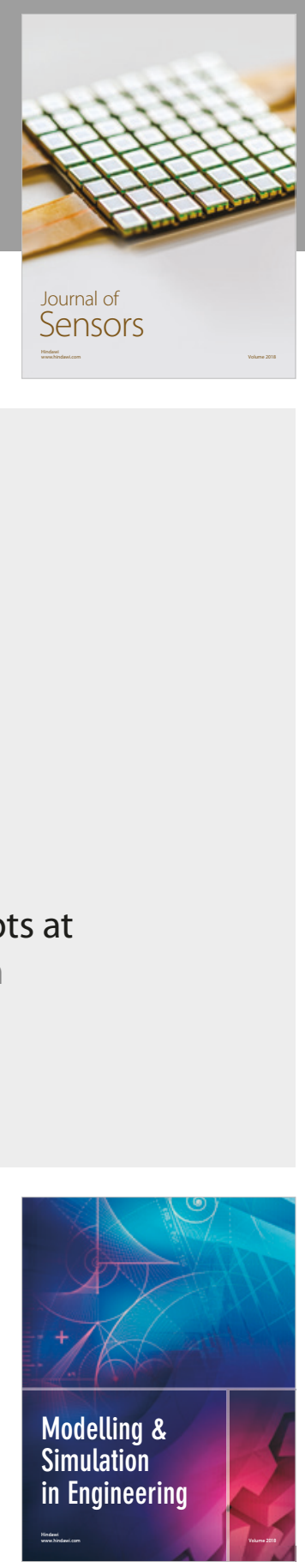

\section{Advances \\ Multimedia}
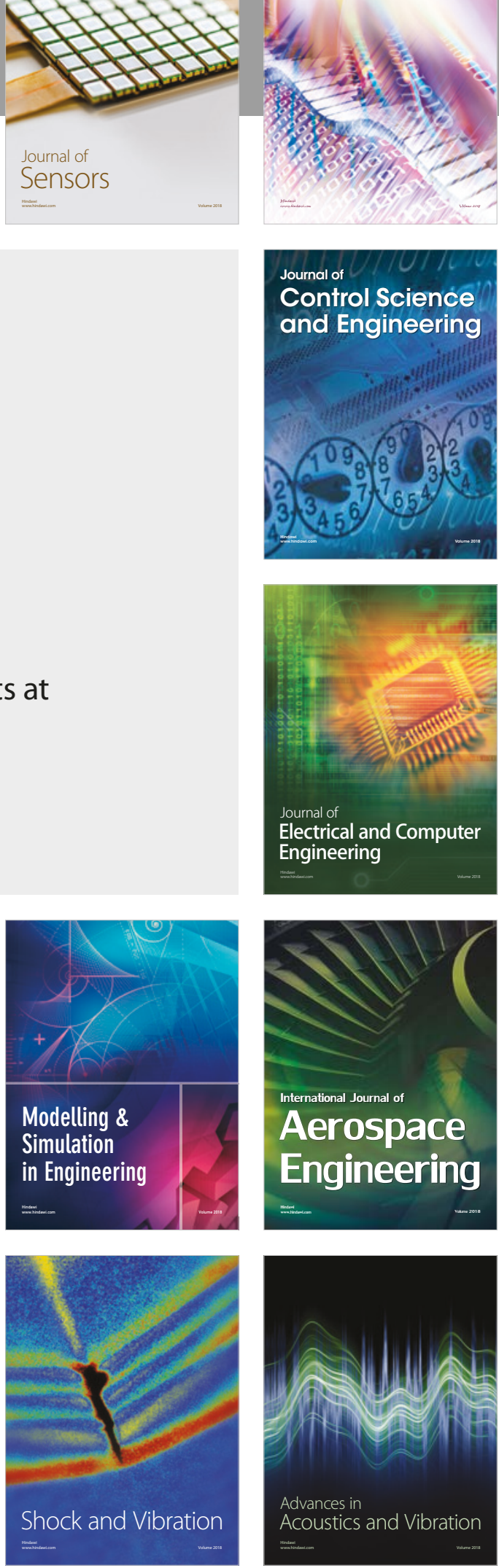